\title{
How to understand the times we are living through
}

\section{Allan Larsson}

\begin{abstract}
The article seeks to understand the long wave of neoliberal economic policies over the last thirty years and its impact on social conditions and the political situation in the West. The financial crisis of 2007-8 marks the end of this long wave, when some of the basic theories imploded, particularly the financial deregulation and the trickle down theories. The end of this wave opened an "empty room", a period without direction and destiny. Governments and political leaders have been stuck in "unfettered globalization" and austerity policies, unprepared to present new policies for widely shared prosperity. The insecurity and the growing inequalities have been exploited by political forces inside and outside the leading political parties, offering simple solutions in the form of building walls and "taking back control". Thus, in the absence of a strong progressive policy response from the established parties, the "empty room" has become "an explosive empty room" of neonationalism and regressive policies.

While our societies have moved to the right in terms of economic and social policy, they have moved left in terms of values such as gender equality and individual rights. A combination of economic stagnation and social decline, "insecurity in times of change", and progress in civil rights and gender equality, has triggered the kind of political and populist revolts that we now see in the US and in many parts of Europe, exploited by conservatives and far-right parties. This can be described as "discontent of declining expectations”. Democracy and democratic institutions are at risk.
\end{abstract}

Keywords: austerity, democracy, globalisation, inequality, insecurity, jobs, markets 


\section{Introduction: How to understand the times we living through?}

During a long life of political engagement I have always felt that I have understood the times I have been living through: Why certain questions dominate the public discourse, why public opinions emerge and fade away, why elections have been won and lost. Now it is different. It applies not only to Sweden, but also to large parts of Europe, and elsewhere in the world, particularly the United States and the United Kingdom. In these well established democracies we have been accustomed to politics operating along a right-left scale, where compromise between parties is an established working method, that provides legitimacy, longevity and stability.

Today, debate is conducted and public policies are based on other scales than those we have been accustomed to, more difficult to understand and to predict. There is a resurgent nationalism, opposing globalisation of the economy and the internationalisation of politics. Simultaneously, we are now witnessing a mix of reactionary conservatism (The Tea Party) and isolationism (Trump) in the USA and a reawakening of "dirigisme" (Poland, Hungary), or a strange mix of nationalism and retrospective imperial ambitions (Brexit). All of this is described as a conflict between the people and the elites, even when the people is represented by an eccentric real-estate billionaire or a upper class Mayor from London.

I started writing this article after a reflection meeting in early summer 2016, organised by Sweden's Minister for Foreign Affairs and the Minister for EU Affairs and Trade. I had tried to explain the political developments we were witnessing by using the concept of the long wave of globalisation, a wave which now has started to lose momentum and attraction. I needed to develop my reasoning if I were to properly explain and convince. That is the purpose of this article.

I have lived through two "long waves", one starting after WWII, built on Keynes' theories, and on the establishment of a new international order, the Bretton Wood compact. That long wave came to an end during the 1970s and the beginning of the 1980s. The next wave, globalisation based on neo-liberal terms, lost its momentum during the financial crisis 20072008. The end of this long wave opened an "empty room" a period without direction and destiny, a period where people started to realise that globalisation and strong market forces had rewarded "the few", while leaving "the many" behind.

I began writing this article in early summer 2016: Before Brexit, the US primaries and all the other political events, in Austria, Germany, Wallonia, Italy and the US, events which made 2016 a year of political upheaval, in the same way as 2008 was the year of financial upheaval. When I started drafting, my intention was to trace the roots of political discontent. After Brexit in the UK and the political conventions in the US, I could imagine a nightmare scenario: A Europe in political disintegration under the leadership of Britain's Conservative government, in parallel development of nationalist parties in France, Germany, Poland, Hungary, with a calculating president Putin in the East and an eccentric and moody president Trump in the West, isolating the US behind new borders, and embracing President Putin. Then, it was a nightmare. Now, it is "the times we are living through". It will take a while before we know what Brexit means, and before we fully understand the consequences of the new Trump regime for the US and for the rest of the world. 
There is however a broad consensus that we can expect fundamental changes to global politics: "For the first time since before World War II, Americans chose a president who promised to reverse the internationalism practiced by predecessors of both parties, and to build walls both physical and metaphorical." ${ }^{1}$ We have reasons to expect political effects in Europe in the form of renewed confidence among the right-wing extremist parties, as many European countries; France, Germany and the Netherlands, probably also Italy, have upcoming elections: "Mr. Trump's success could fuel the populist, nativist, nationalist, closed-border movements already so evident in Europe and spreading to other parts of the world." 2

Now, at the beginning of 2017, with this post-Trump-inauguration version, I am convinced that the key question is a threat to democracy as a political system, to the democratic values and to democracy as a way of organising public life. Will illiberal leaders in Europe and in the USA respect democratic institutions and traditions? Will they allow elections on equal terms, or will they use political and digital power to introduce and cement authoritarian systems? Or, to use an answer by Anne Appelbaum to her own question in an article in the Washington Post: “There aren't any obvious ways to fight illiberal democracy democratically."3

The intention of this article is therefore to contribute to a better understanding of the times we are living through, not to introduce new progressive ideas. I will sum up problems, presenting them in the form of a concerned citizen's questions to the next generation of progressive economists, scholars and policy makers. It is for the new generation to come up with the new ideas, theories, intellectual tools and political strategies for a new global agenda.

\section{The end of a long political wave - how come?}

\section{From Bretton Woods to Washington Consensus}

How can we understand these times? The answer is that we are witnessing the end of a long wave that has carried the economic and political development since the end of the 70's and the beginning of the 80's. Economic historians used to explain such long waves with emergence of new technology, economic political leadership, governance and new driving economic theories. Here I focus on economic theories and political leadership as the prime drivers, and technology as a supporting mechanism.

The inter-war wave was halted when financial markets collapsed in 1929 and when the prevailing political economic theories failed to offer a way out of the crisis. The post-war reconstruction and development wave was based on Keynesian economic policy theories about how governments through active politics would promote growth, stability and a "widely shared prosperity". This wave had its global institutional basis in the Bretton Woods system of fixed exchange rates and economic co-operation, regionally and globally. The US became the leading force in this period of reconstruction, industrialisation and trade.

This wave faded out during the 1970's. In the light of the 1970's economic development The oil price shock, tripling of oil prices 1973, high inflation and weakened economic growth, "stagflation"; the underlying theories were increasingly contested. The critique was based on 
research findings, claiming that the economy would work better if markets were given greater roles, and Governments correspondingly less. These theories had an impact in politics and media and soon formed a new mind-set with great impact.

These new ideas became the basis for the political success of the Republican party in the US and the Conservative party in the UK; two countries that served as role models, backed with great authority by international organisations such as the IMF, the World Bank and the OECD, spreading the political ideas and economic theories to governments and central banks all over the world. This new paradigm, the "Washington Consensus" ${ }^{4}$ came to run parallel with the major shift in technology, the digitalisation of the global community. Two major economies, first China and then India, were reformed and became part of a global economy. One billion workers were integrated in the global division of work.

The new market forces, the new market economy and new technologies became mutually supportive. It was a wave which freed productive forces and promoted innovations, presented a whole new basis for the international division of labour and contributed to millions of people moving out of poverty, while at the same time allowing for increasing amounts of wealth and power to be concentrated among small minorities, leading to growing inequality and to instability in the global financial system.

\section{The economic theories behind the political wave}

This long wave, the Great Transformation, to quote André Sapir5, is now about to lose momentum, and will be replaced with something else. To explain why this wave is about to peter out, we need to understand some of the central elements in this financial policy paradigm, as prescribed by international organisations which have acted as yardsticks and benchmarks for actors on the financial markets. ${ }^{6}$

One of these central elements was the idea that deregulation of the financial market would create both financial stability and economic growth. It was thought to be a financial system superior to the current regulation. Two theories were presented as grounds for deregulation. One, the Efficient Market Hypothesis, states that nothing could be more rational than the free market, which gathers and structures all available information. The second, the Rational Expectations Hypothesis, meant that all actors in the financial markets have access to perfect information about the future and make rational decisions. These two theories, that markets are effective and that actors are rational, were together a guarantee that the financial crisis which had occurred in the past would no longer be possible. ${ }^{7}$ 


\section{Economic performance I: Stability}

It was this set of theories that failed when the banking crisis hit in 2007-2008 and plunged the global economy into the deepest crisis since the 1930's.

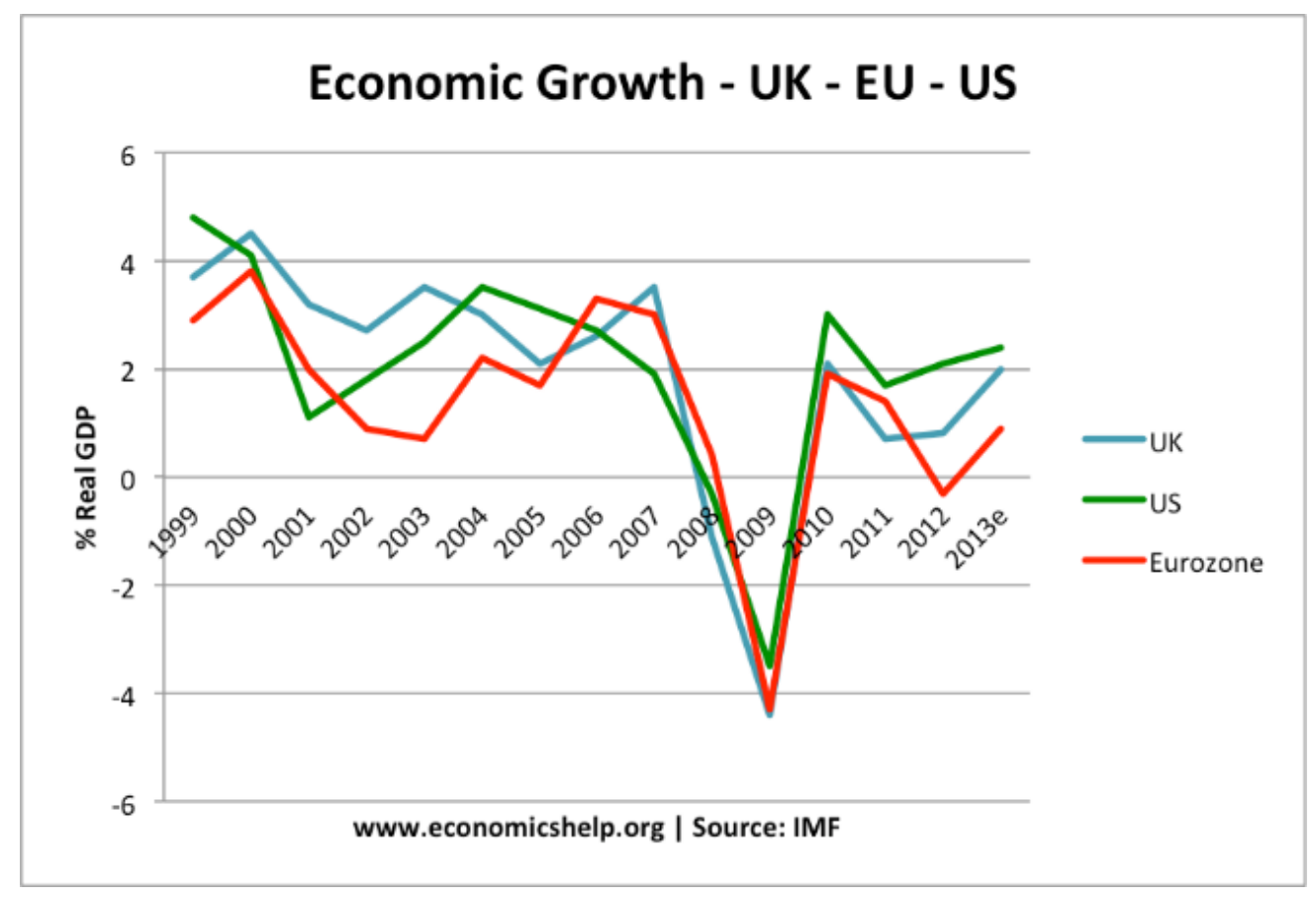

Figure 1: Economic growth UK, US, US

The background is well described in many books and articles written after the crises: The growth of the financial system, the shadow banking system, the securitisation of risks, the confidence in the financial system and in the Federal Reserve. Here is one glimpse of the precrisis thinking. At the annual Fed conference in Jackson Hole in 2005, the last year with Alan Greenspan as chairman of the bank:

"The typical paper on the financial sector at that time described in breathless prose the dramatic expansion of financial markets around the world. It emphasised the wonders of securitisation, which allowed banks to package risky housing or credit cards together and sell claims on the package in the financial market. Securitisation allowed a bank to get the risky loans off its books.”

This writes Raghuram G. Rajan, at that time professor at Chicago Booth School of Business in his book "The Fault Lines" (2010), adding that some of the papers focused on "whether Alan Greenspan was the best central banker in history, or just among the best" ${ }^{8}$. It was not popular to deliver a different message, which Rajan did, in a speech with the title Has Financial Development Made the World Riskier?: 
"If those securities ran into trouble, the banking system itself would be at risk. Banks would lose confidence in one another... The interbank market could freeze up, and one could well have a full-blown financial crises.”

Professor Rajan was not the only one making a correct analysis of the situation. Nouriel Roubini, Kenneth Rogoff, and Niall Ferguson did the same. However, the big majority of leading economists were enthusiastic supporters of Greenspan's policies. Rajan gives an plausible explanation to the excesses in the financial markets, by pointing to stagnating income for the middle class and growing income inequalities:

"The everyday consequences for the middle class are a stagnant paycheck as well as growing job insecurity. Politicians feel their constituents' pain but it is very hard to improve the quality of education, for improvements requires real and effective policy change in an area where too many vested interests favour the status quo.....Therefore, the political response to rising inequality: whether carefully planned or on an unpremeditated reaction to constituent demands, was to expand lending to households, especially lowincome ones. The benefits: growing consumption and more jobs, were immediate, whereas paying the inevitable bill could be postponed into the future ... In the United States, the expansion of home ownership: a key element in the American dream, to low- and middle income households was the defensible linchpin for the broader aims of expanding credit and consumption. But when easy money pushed by deep-pocketed government comes into contact with the profit motive of a sophisticated, competitive and amoral financial sector, a deep fault line develops."

With extensive experience of deregulated financial markets, Lord Turner, chairman of Britain's Financial Services Authorities, stated in his book "Economics after the Crisis", that "the pre-crisis confidence in the free financial markets was profoundly misplaced" 9 . He illustrates this with details on how the rational market completely miscalculated the risks of the financial system:

“...risks to bank creditworthiness had fallen steadily between 2002 and 2007, reaching a historical low in the early summer of 2007, the very eve of the worst financial crisis in 70 years. Neither CDS spreads, nor bank equity prices, provided any forewarning of impending disaster. Instead they validated and strongly reinforced a surge of over-exuberant and underpriced credit extension to the real economy."

Turner rejects the public choice theory, the Washington consensus and the econometric models, i.e. the dominant elements of the last 30 years of economic policy theories.

"It is now obvious that this dominant ideology was wrong, failing to allow for the potential downside of the instability that increased financial complexity might produce. And it failed to consider this possibility because it was based on the assumption that financial markets are rational and equilibrating, rejecting the Keynes/Minsky insights that financial markets can be subject to self-reinforcing swings of irrational exuberance and then despair." 
Turner thus joins those who warned that one must be very careful with the teachings and practices of economics as a narrowly defined discipline with no connection other disciplines: "We need to recognise that economic policy choices are political rather than narrowly economic in nature.”

The global financial flows constitute an immense force. In combination with the herd mentality that exists among actors in the financial markets, these markets are the opposite of what Alan Greenspan and his closest circle of like-minded colleagues and friends dreamed of; they are destabilising, not stabilising. Even Alan Greenspan, the chief spokesman for the market' supremacy, was at the end forced to admit that the notion of rational markets was flawed: "The models failed at a time when we needed them most, The Fed model failed. The IMF model failed." ${ }^{10}$ To express it in a more popular manner, as Queen Elisabeth did when she visited London School of Economics: "Why did nobody notice it?" ${ }^{11}$

Will it be different next time? After the 2013 Jackson Hole meeting, Robin Harding, summarised the meeting in an op-ed in the Financial Times: "The world is doomed to an endless cycle of bubbles, financial crisis and currency collapse. Get used to it .... All their discussions of the international financial system was marked by a fatalist acceptance of the status quo ... we still have no way to tackle imbalances in the global economy and that means new crisis in the future”. Alan Blinder, a highly regarded economist and policymaker, asks in his book "After the music stopped” (2013) if the new US regulation, the Dodd-Frank reform "will make history of financial crisis" and gives the following answer: "Certainly not. Will it make them rarer? Maybe; time will tell. But there are good reasons to believe it will reduce the severity and costs of future financial excesses." 12

The same message comes out of a new book "Makers and Takers” by Rana Foroohar (2016) on the rise of finance and the fall of American business. Her view is that eight years after the financial crisis the key lessons of 2008 still remain unlearned. "Policy makers get caught up in the details of regulating "Too Big to Fail” banks, but the problems in our market system are much broader and deeper than that.” She gives the following examples:

- Only about $15 \%$ of all the money in our market system actually ends up in the real economy: the rest stays within the closed loop of finance itself.

- The financial sector takes a quarter of all corporate profits in the USA while creating only four per cent of American jobs.

- The tax code continues to favour debt over equity, making it easier for companies to hoard cash overseas, rather than reinvest at home.

- The biggest and most profitable corporations are investing more money in stock buybacks than in research and innovation.

- And, still, the majority of the financial regulations promised after the 2008 meltdown have yet come to pass, thanks to cosy relationships between our lawmakers and the country's wealthiest financiers.

I give the last word in this discussion on the role of financial system for macroeconomic stability to Lord Turner. In his book “The Debt and the Devil” (2016) Lord Turner argued for tougher reform of the market for credit creation. He reminds us that the pre-crisis orthodoxy treated free market private credit creation as by definition optimal, and fiat money creation as 
in all circumstances dangerous; the work indeed of the devil. But in fact we face a balance of risks and benefits:

\begin{abstract}
"There is no utopia of finance for all, which will result from the operation of free markets subject only to a simple set of macroeconomic rules. We cannot avoid the need to intervene to offset the inefficiency and instability that the free financial markets will inevitably generate. We face a choice of imperfections and some of them are unfixable. Rather then pursuing an unattainable utopia, we should identify where free markets have the greatest potential to diverge from social optimality, and design public policies in response."
\end{abstract}

\title{
Economic performance II: Productivity and growth
}

The deregulation of the financial market was one of the constitutive elements of the last decades of globalisation on neo-liberal terms. Along with the parallel digitisation of the global economy, strong productive forces were freed, laying a new foundation for the international division of labour, and lifting millions and millions of people out of poverty. However, all these advances; the internet, mobile broadband and devices, artificial intelligence, robotics, advanced materials, improvements in energy efficiency and personalised medicine, have not boosted measured productivity growth in Europe and the USA.

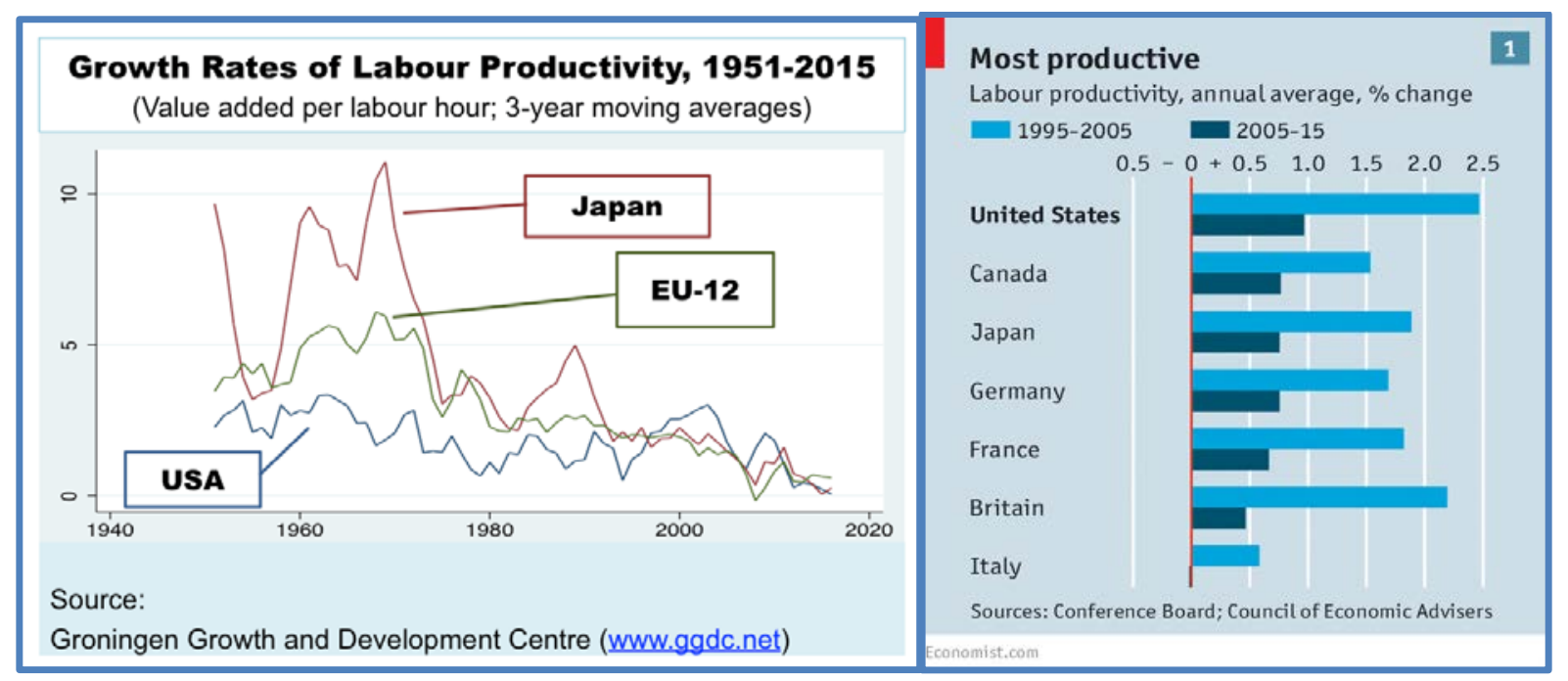

Figure 2: Growth rates of labour productivity, 1951 - 2015

Productivity growth has slowed across nearly all advanced economies: See chart to left on the long term development of productivity in the US, Japan and EU 12 and, to the right, on the development over the last two decades for some of the leading countries in the west. The figures are striking ${ }^{13}$ : Productivity in the US has decreased from 2,5 percent before the financial crisis to one per cent during the last ten years, UK down from 2.0 to 0,5 , Italy down from 0,5 to 0 . Over the last ten years, GDP per capita has been almost stagnant in Europe. 
The EU has stopped catching up with the US, and now risks falling back. It remains difficult to explain why. Daniel Gros, head of the think tank CEPS in Brussels, writes in a critical analysis of the EU structural reform policies. ${ }^{14}$

“The recipe almost universally recommended has been "structural reforms", a central element in the neoliberal reform strategies. But this is a recipe that has been tried intensively in recent decades, and it has failed. Nevertheless, the IMF and the OECD again promise output gains of between four and twelve per cent from a set of product and labour market reforms. This call for "more of the same" is difficult to sell to a public which sees its living standards stagnating, despite all the integration and reform activity at the EU and the national level.”

Daniel Gros' advice to European policy makers is that they should be careful not to promise too much from structural reforms, until they can diagnose with some precision the forces that push Europe backwards.

A major source of the recent productivity slowdown has been a shortfall of public and private investment caused, in part, by a hangover from the financial crisis. It has also been caused by self-imposed constraints; an anti-tax ideology that rejects virtually all sources of new public funding; a fixation on deficits at the expense of the deferred maintenance bills we are passing to our children, particularly for infrastructure, as pointed out by president Obama when he made a review of the economic situation in the USA at the end of his Presidency. ${ }^{15}$

The failure of the neoliberal drive for structural reform to give a push to productivity might have a natural explanation. In his book “The Rise and Fall of American Growth" professor Robert J. Gordon presents a comprensive analysis of productivity development over a couple of centuries. His conclusion is that the high productivity growth in the US until 1970 was unique, many of these inventions could only happen once, and others reached natural limits:

"The timing of the stream of innovations before and after 1970 is the fundamental cause of the rise and fall of American growth engine.”

Professor Gordon does not give any hope for a revival of productivity in the years to come. There are several headwinds, which will leave virtually no room for growth over the next 25 years in median disposal real income per person. One such headwind is rising inequality, another is education attainment, which is no longer rising as rapidly as before. A third factor is demography, with a shrinking share of the population in working age, and a growing imbalance between federal debt and $\mathrm{GDP}^{16}$. A recent study by Swedish economists presents similar conclusions ${ }^{17}$. Their overview of prospects for economic growth during the coming 50 to 100 years exposes, not surprisingly, great uncertainty and a large range of possible outcomes. The projections, however, lean more towards the negative side, i.e. there are more factors indicating headwinds and lower growth rates, than factors pointing towards good prospects for economic growth.

The historical review shows that the currently dominating perspective on economic growth, as a natural state of the economy, was not expected by economists prior to the high growth period in the middle of the 20th century. Instead most economists expected mature economies to transition to lower growth rates or a steady state economy. In a short period of time this 
perspective was almost lost, and replaced by a dominant growth paradigm in which economic growth is assumed to persist.

\section{Economic performance III: Distribution of income and wealth}

Another central element of this long wave of globalisation on neo-liberal terms was the notion on "trickle-down", i.e. that the market would best manage distribution of income and wealth with minimal political interference. It was said there was no need to worry about income inequality; job and incomes would in all circumstances trickle down to those who were in need. The important thing was that there were incentives to work, invest and get rich. Growing inequality was a price to be paid to achieve economic growth. This notion has in recent years been increasingly questioned, based on the fact that the outcome has been completely different from what the theoretical models promised ${ }^{18}$. It is most evident in the US, where the income of the working class and the middle class have been stagnant for a long time, while income and wealth have gathered at the top at unimaginable amounts. The effects of globalisation, digitisation and the lack of political measures to balance or offset the strong market forces have effectively halted the incomes of the working and middle class.

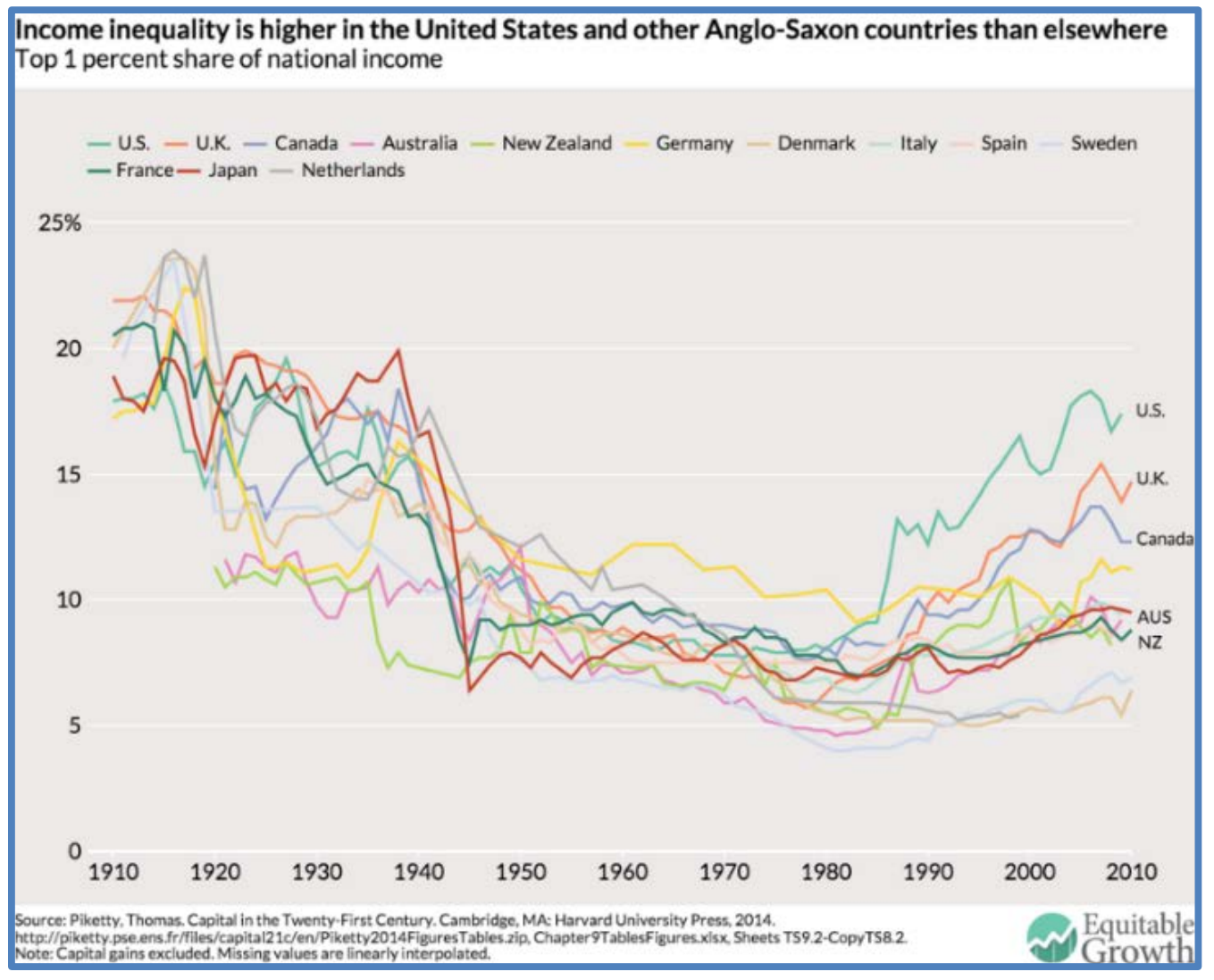

Figure 3: Income inequality

Here are some charts illustrating distribution of income over longer and shorter periods of time. The first one shows income distribution over a hundred years, from 1910 to 2010 for a 
number of OECD-countries, measured as the top 1 per cent share of national income. Income inequality decreased until the 1980s, followed by increased income inequalities particularly in US, UK and Canada, to a lesser extent in other countries. The widening of the income gap coincides with the long wave of deregulation and weakening of labour markets, the introduction of new technologies and the opening up of China and other Asian economies.

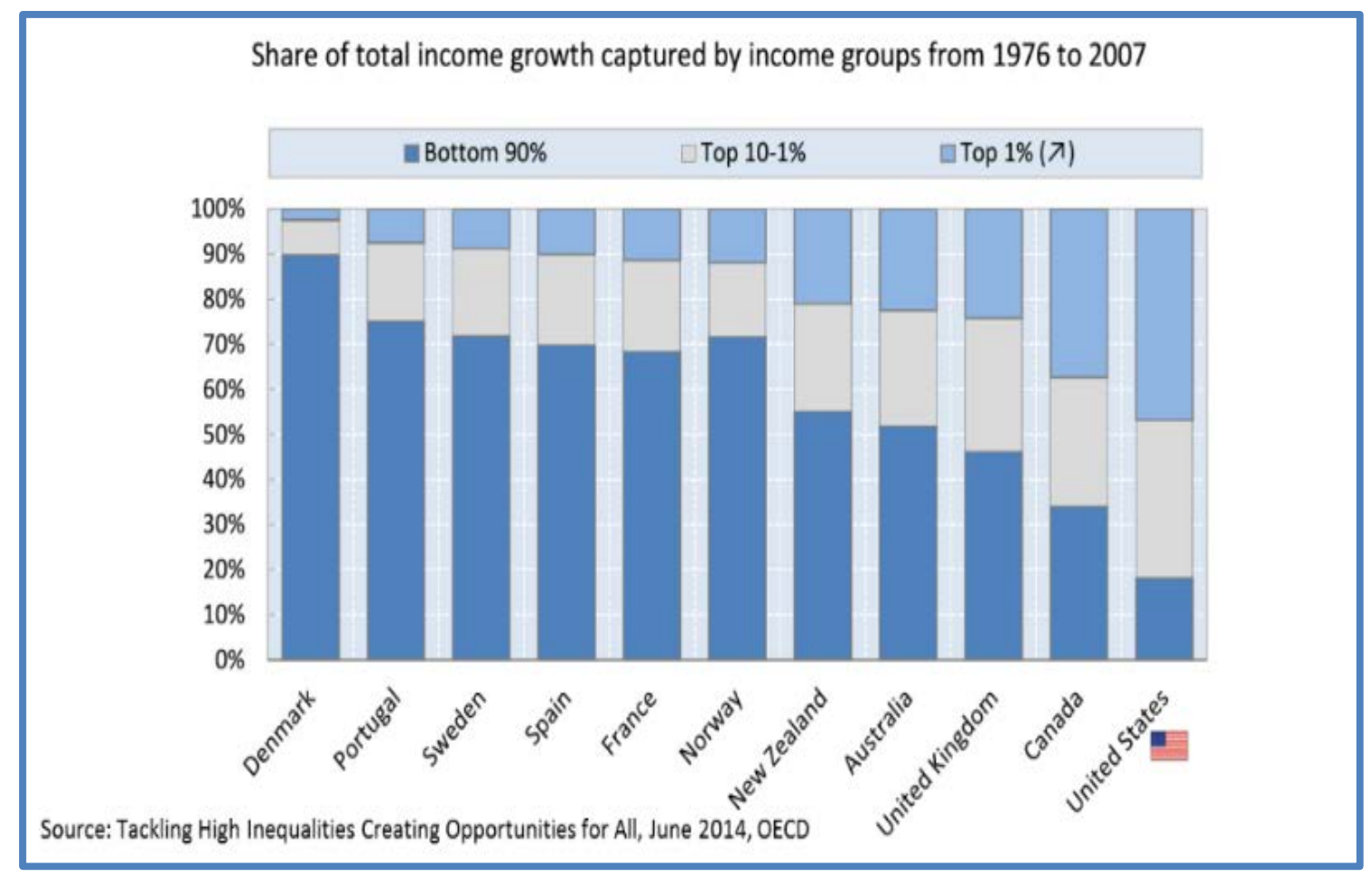

Figure 4: Total income growth by income groups

The second chart, above, from the OECD, shows share of total income growth captured by income groups from 1967 to 2007. This is another way of telling the same story in more detail It is the Anglo-Saxon countries: USA, UK, Canada, Australia and New Zealand, that have gone furthest in rewarding the few and leaving the many behind. 


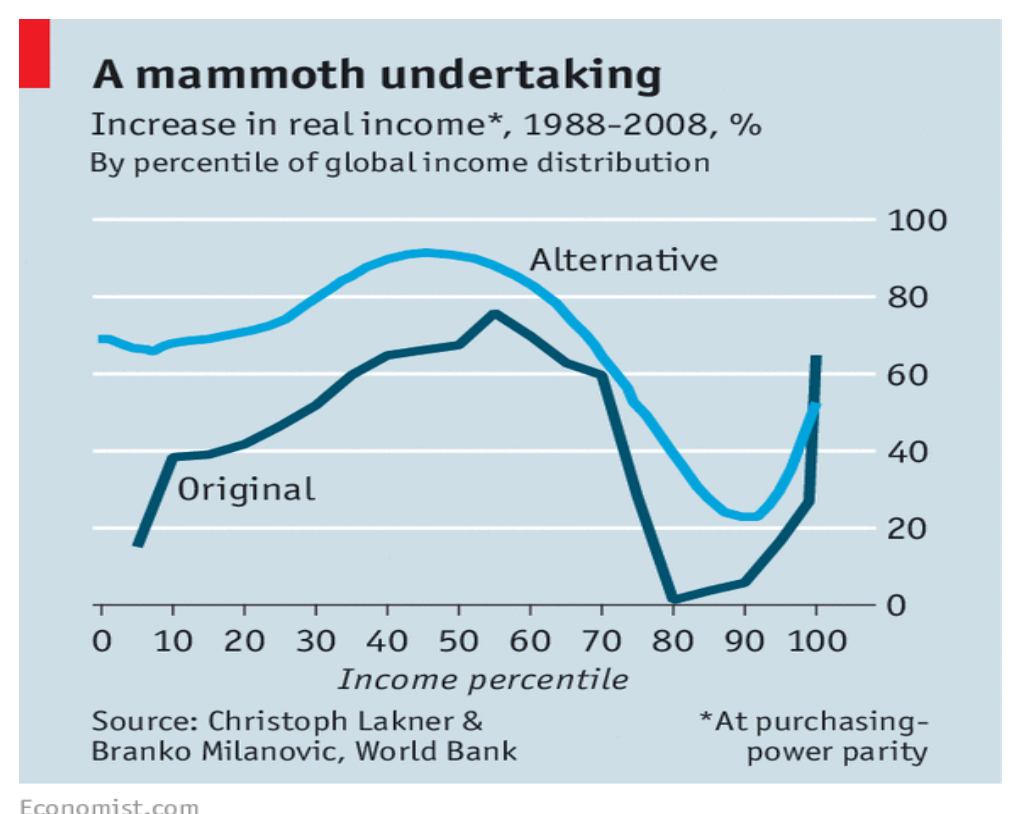

Figure 5: Income percentile - real growth

The third one is the famous "elephant curve" on global income distribution over 30 years,. The distinctively shaped chart, in black, summarised the results of a huge number (196) of household surveys across the world. It was created by ranking the world's population, from the poorest $10 \%$, at the left sida, to the richest $1 \%$ to the right hand side, in 1988 and again in 2008. At each rank, the chart showed the growth in income between these two years, an era of "high globalisation" from the fall of the Berlin Wall to the fall of Lehman Brothers. The black curve in this chart, illustrating income development, brings three important messages: First, it shows that China's middle classes have gained handsomely in the era of globalisation. Second, it confirms that the lower middle classes in rich countries have fared less well. Third, the world's rich, the top 1 per cent, have had a great time.

The light blue curve illustrates more or less the same development, but in a less drastic way. It shows how each income group in each country in 1988 fared over the subsequent 20 years. In its shape, the chart looks recognisably elephantine, but the top 1\% do markedly less well in this alternative chart than in the more famous one, and even the worst performing groups (now around the 90th percentile) boast income growth of $20 \%$ or more over 20 years. The elephant shape remains, even if its dimensions are different. ${ }^{19}$

McKinsey Global Institute ${ }^{20}$ has presented a parallel study "Poorer than their parents?" showing some striking facts on stagnant or falling real income in 25 high-income countries. The report compares the development between 1993-2005 and 2005-2014, two periods of about 10 years, which makes it possible to capture the effects of the financial crisis. During the first period, 2 percent of the households were affected by stagnant or falling real incomes, during the later period, 65-70 percent on average had seen their real incomes remain the same or decrease. This applies to wages and other incomes before taxes and income transfers. 


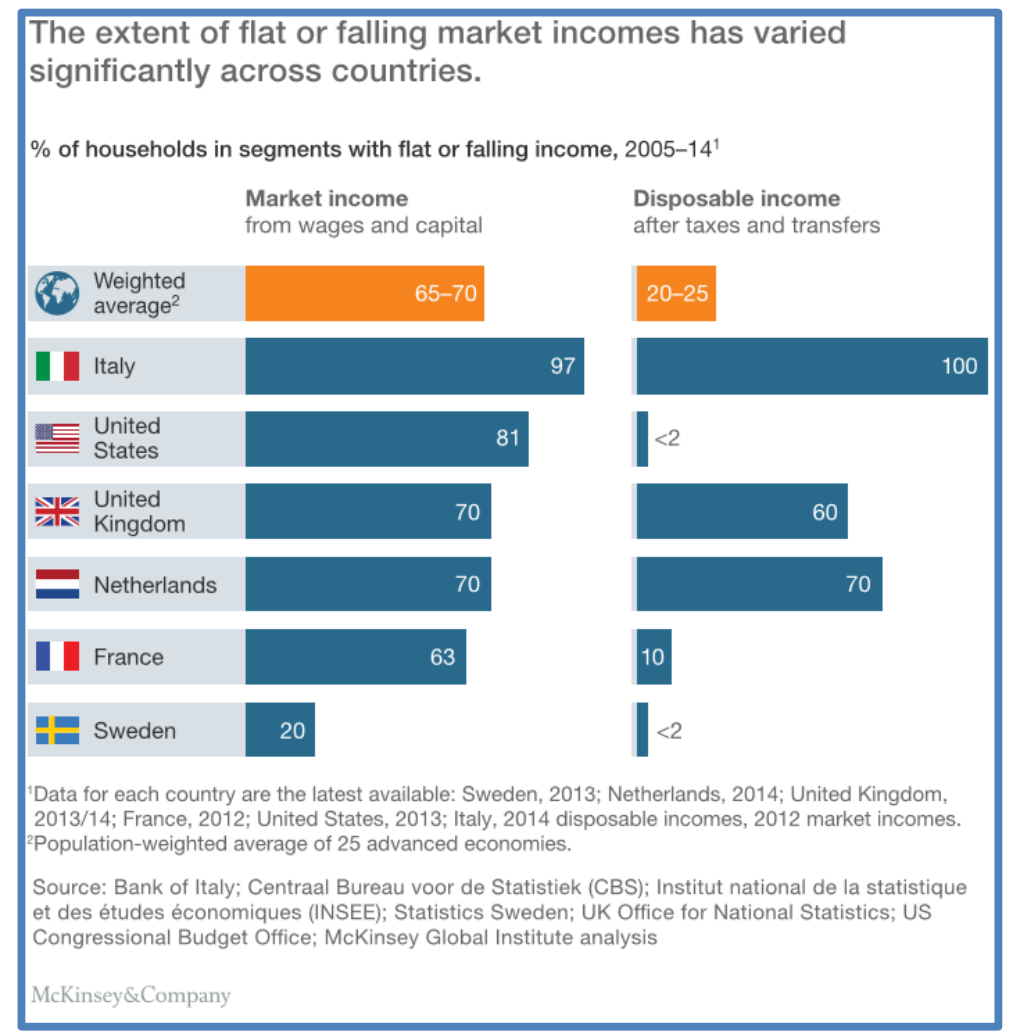

Figure 6: Income segments with flat ort falling income

The result will be better after redistributive measures. However between 20-25 percent of households have been "left behind":

"The economic and social impact is potentially corrosive. A survey we conducted as part of our research found that a significant number of those whose incomes have not been advancing are losing faith in aspects of the global economic system. Nearly one-third of those who are not advancing said they think their children will also advance more slowly in the future, and they expressed negative opinions about free trade and immigration.”

There are two countries that differ from the general picture, the US and Sweden. The McKinsey study offers the following explanation:

"The encouraging news is that it is possible to reduce the number of people not advancing. Labour-market practices can make a difference, as can government taxes and transfers: although the latter may not be sustainable at a time when many governments have high debt levels. For example, in Sweden, where the government intervened to preserve jobs during the global downturn, market incomes fell or were flat for only 20 percent of households, while disposable income advanced for almost everyone. In the United States, lower tax rates and higher transfers turned a decline in market incomes for four-fifths of income segments into an increase in disposable income for nearly all households.”

While incomes fell or were flat for 20 per cent of Swedish households, redistribution reduced it to 2 per cent. 
There has always been a criticism of the "trickle-down" theory in the political debate, however the political sphere, as defined by neoliberal redistributive policy ideas, has remained indifferent in this regard. An important contribution to the rethinking of these theories were presented by Thomas Piketty a couple of years $\operatorname{ago}^{21}$. He points out that inequality threatens democracy as well as the socio-economic foundation of which democracy stands on, as a concentration of wealth entails a concentration of power and reduces societal participation of the vast majority. Society's economic foundations are threatened, he says, when growth is weak, and income inequality and wealth distribution increases.

Parallel to such research, there is an ongoing rethink among leading global governmental organisations. In a unique joint document, the IMF, World Bank, OECD and ILO presented in 2015 to the G20 Ministers of Labour and Employment and Ministers of Finance, the following new message on inequaity and economic growth:

"Rising inequality raises concerns because it can have a corrosive effect on social and political cohesion. Further, a growing body of research also demonstrates that high inequality may lead to slower as well as less sustained economic growth. This negative impact on growth occurs through various channels, including lowering consumption, under-investment by firms in the face of slack demand, less government revenue, and less investment by low-income households in education and skills. ... The new body of evidence contrasts with an earlier view that inequality was a price that had to be paid for higher growth. In fact, the evidence shows that the effect can run in the opposite direction, with more equality leading to higher growth.”

Given the commitment of the G20 to raise overall economic growth ... the attention to inequality is particularly appropriate and necessary. And as global and G20 growth have slowed again this year, it has become a matter of urgency".

This message has recently been reinforced by the OECD in a report on the weakened growth and the fundamental changes underlying these conditions: ${ }^{22}$ 


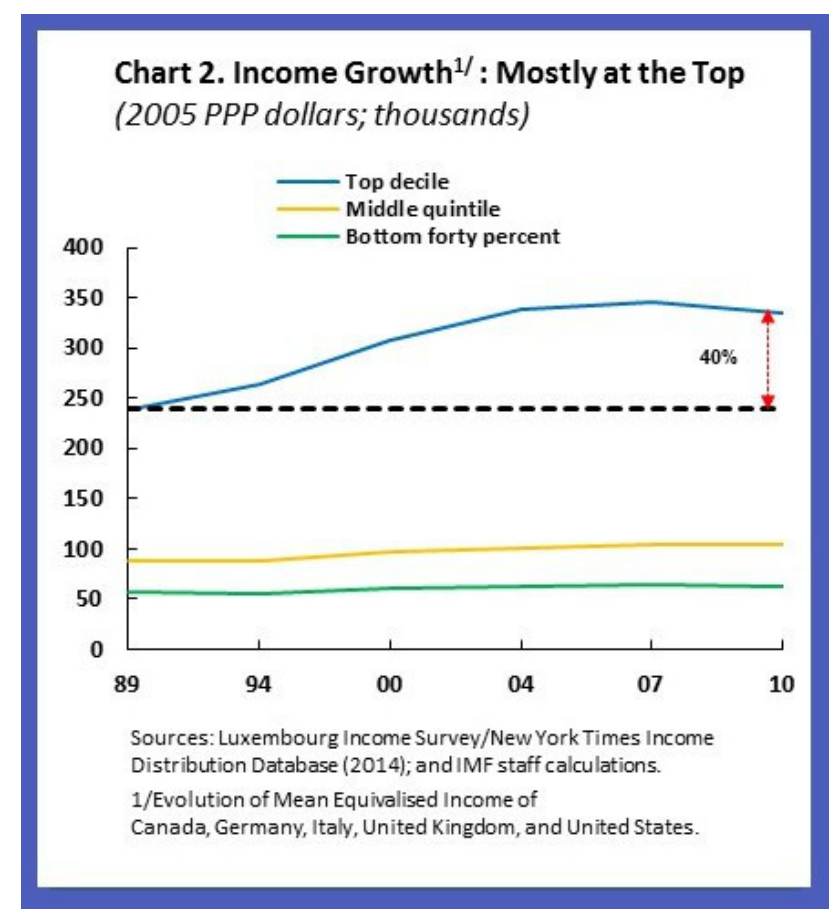

Figure 7: Income growth per quintile

"There is a risk of a vicious cycle setting in, with individuals with fewer skills and poorer access to opportunities often confined to operate in low productivity, precarious work and, in many emerging market countries, in the informal economy. This reduces aggregate productivity, widens inequality and ultimately undermines policy efforts to increase productivity and growth."

To understand income distribution and its political consequences, a deeper look is required into how the labour markets are working, and how income is created and distributed. It might be good to start with a simple depiction of "the two speed labour market". According to the OECD, every year, around 20 per cent of the jobs are created or destroyed, and around one third of all workers are hired or separated from their employer ${ }^{23}$. These large flows of jobs and workers are driven by a continuous process of labour reallocation, both across industries and between declining and growing firms within the same industry. This process is an important source of productivity gains, since more productive firms expand at the expense of less productive firms.

Many people move from one job to another without any unemployment spell. Others will lose their jobs without immediately finding a new one. This is " the two speed labour market”, i.e. a rapid shift in the demand side of the labour market to higher skill requirements and a slower rate on the supply side, in the upgrading of professional skills and competence. Those who lose their jobs without finding a new one will need a new start in the form of education, training, rehabilitation or othe forms of support in transition to new jobs. Such efforts are poorly developed in many countries. That applies to the US as well as Europe.

The US has now found that the flexible labour market, with weak institutions and weak social support, leads to an increased portion of men who are neither employed nor do they actively search for employment. The portion of the male population that is neither working, seeking 
employment, getting education or are too old to retire, has more than doubled in the last 50 years, even if the population overall has better health and is better educated. Today, despite a generally low unemployment, one out of six men between the ages of 25-54 are without jobs $^{24}$. It is even worse for this age group than in the European countries, such as in France; the kind of labour regime that applies in the US seems to be no solution to these problems. If this trend continues in the USA, a quarter of men between 25 and 54 will be left out of the labour market within one generation. Lawrence Summers has noted how such exclusion has political effects: "A society where many adults are without vocation is prone to embrace toxic populist politics". ${ }^{25}$

There are more well developed safety nets in Europe, mostly in the form of income support, less in the form of springboards to new more qualifying jobs. For those without employment, an average of 10 percent will get a new start through education, rehabilitation or other active measures. 90 percent must find a new jobs in the emerging digital economy with increasing demands on competence and adaptability. Some find new jobs fairly quickly, although for the large part, there are few bridges back to "gainful employment" for unemployed. It is an important explanation for the extensive long-term unemployment that constitutes a large part of the unemployment rate, which persistently remains at 10 percent of the workforce. ${ }^{26}$

To sum up: In markets for goods and services, competition kills off the least productive products and enterprises, which guarantees continuous economic progress. Labour markets are different. People should be able to work productively for at least 40 years. Hence the policy emphasis needs to be on supporting them optimize their productive performance during working age. This requires a policy environment that is both pro-active and defensive enabling people to invest in skills and abilities so as to master structural changes, while creating safety nets that deter a race to the bottom and avoid the risks of poverty and exclusion for people who face difficulties.

\section{The final verdict?}

A distinct and highly critical summary of the state of macroeconomics was delivered in the beginning of 2016 by Paul Romer, at that time professor at Stern School of Business, New York University, now chief economist of the World Bank, a highly regarded economist with a research background from Chicago, MIT, Stanford and Berkely. His main contribution to macroeconomics is a new growth theory, based on the difference between land, labour and capital on the one hand, and knowledge on the other. While land, labour and capital are rival goods, which can only be used by one person/enterprise at a time, knowledge is a non-rival good, a resource which can be used simultaneously by a great many people.

In the first sentences of the abstract of his lecture, he provoked a great number of fellow economists: "For more than three decades, macroeconomics has gone backwards. The treatment of identification now is no more credible than in the early 1970s, but escapes challenge because it is so much more opaque". He attacked macroeconomic theorists for dismissing mere facts by feigning an obtuse ignorance about such simple assertions as "tight monetary policy can cause a recession." Their models attribute fluctuations in aggregate variables to imaginary causal forces that are not influenced by the action that any person takes. 
"A parallel with string theory from physics hints at a general failure mode of science that is triggered when respect for highly regarded leaders evolves into a deference to authority that displaces objective fact from its position as the ultimate determinant of scientific truth". ${ }^{27}$

\section{The legacy of the long wave}

The collapse of basic theories behind the long wave of globalisation: the Efficient Market Hypothesis, the Rational Expectations Hypothesis and the trickle-down theory and the impact of these theories on public policies, explains some of the political developments that we now see in the US and in Europe. Over a long period of stagnant incomes for large parts of the population, the rich could accumulate incomes and wealth on a massive scale. When the financial crisis hit Wall Street, and then further spread onto Europe, citizens had to pay to save the banking system, while the financial elite could continue accumulating wealth. The social contract between citizens and society; the notion that the society can be made better through hard work and that everyone should have their share of the profits, was undermined. Public dissatisfaction grew, although they did not align themselves along a traditional rightleft scale, but rather in protest against the leading political parties, to the right and left, who were associated with the long wave of globalisation and the financial world that profited from globalisation.

As a result of the extensive and growing discontent, the political landscape has changed and the parties that have long been governing in the continental Europe have lost legitimacy and political support, while the corresponding parties in the US and the UK are undergoing internal and polarising changes. This is seen most dramatically within the Republican party, that now has to live with Donald Trump as their president during the coming four (?) years, a president in opposition to the establishment, globalisation and the US role in the world, traditional republican interests and priorities; an anti-elite campaigner, now filling the new adminstration with the top of the right wing elites of business, the intelligence commuinity and defence.

\section{"The explosive empty room"}

\section{A decade of discontent}

We are living through a decade of discontent. This article is an attempt to understand the times we are living through, the end of the long political wave from the 1980s, "The Great Transformation", and how the fundamental economic theories behind this wave imploded in the financial crisis in 2007-2008. The end of this long wave opened an "empty room" a period without direction and destiny, a period where people started to realise that globalisation and strong market forces had rewarded "the few", while leaving "the many" behind. In this "empty room" the governing political parties have been stuck in "unfettered globalisation" and in austerity policies. They have been unprepared and unwilling to present new policies and strategies for jobs and widely shared prosperity; path-dependence is strong! 
Insecurity and growing inequalities have been exploited by political forces inside and outside the leading political parties, offering simple solutions in the form of "building walls" and "taking back control". Thus, in the absence of a strong progressive policy response from the established parties, the "empty room" has become "an explosive empty room" of regressive policies; with the UK referendum as a first explosion, and the US presidential election as The Big Bang.

In the situation of income stagnation and inequality, social decline and political discontent, there is another dimension that must be observed. The cultural dimension is well described by Katrine Marcal in the Swedish newspaper Aftonbladet, as a dimension of a contraposition between liberal progress and economic policy during the long neoliberal wave:

"The political compromise that has prevailed in the western world for the last thirty years has been a combination of (neo)liberal economic reforms and (in this context) radical policies regarding women's, LBGTcommunity's and ethnic minority rights. In this sense, societies have culturally moved to the left wing, while economically moving to the right. Right-wing parties, that used to oppose feminism and homosexuals' right to marry, have slowly accepted these values. Similarly, the left parties have learned to adapt to privatisations and deregulations of the economy. With the financial crisis and its aftermath, this compromise has imploded, and we are now living in a wave of populism." 28

The combination of financial stagnation, social decline and liberal progress is described as one reason for triggering the kind of nationalism and populistic revolts that we are now witnessing in the US and in a number of places in Europe. "Americanism, not globalism, will be our credo," says Donald Trump, “America First” was the main message in his inauguration speech. It is the right wing, the far right, that has taken the role as representative of the social discontent, not the left wing: A discontent that is double-edged, socially and culturally, based on social conditions as well as nationalism and xenophobia.

\section{The American paradox}

The political developments in the US is paradoxical. On one hand, economic development is stronger than in Europe, and on the other hand, there are greater polarisation, discontent and deeper contradictions than ever before. The Republican Party, exploiting the discontent, is now holding the Presidency, a majority of the Senate, the House of Representatives and the executive power, to appoint new conservative members of the Supreme Court. 


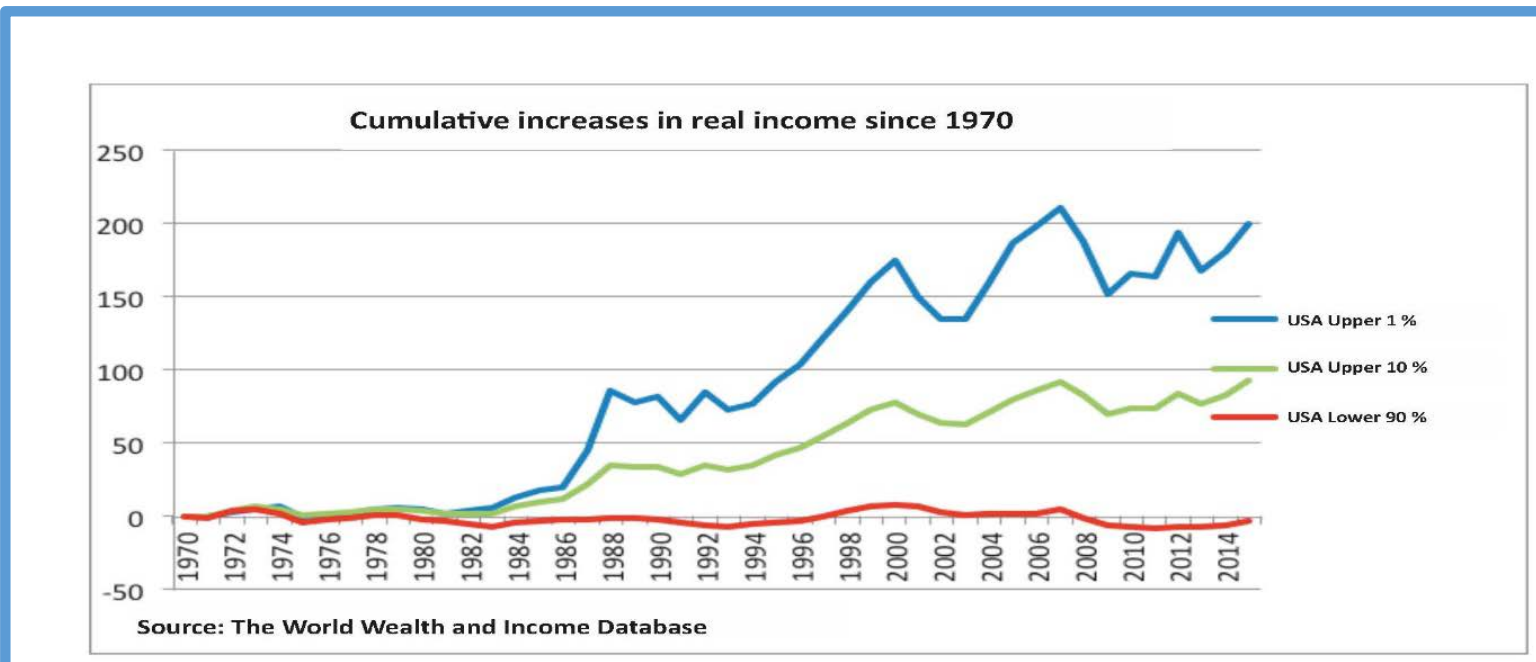

Figure 8: Cumulative increases in real income since 1970 (USA)

President Obama has made an issue of the fact that over the past 25 years, the proportion of people living in extreme poverty has fallen, from nearly 40 percent to under 10 percent, and that American households in 2015 enjoyed the largest income gains ever and the poverty rate fell faster than at any point since the 1960s.

However, decades of declining productivity growth and rising inequality have resulted in slower income growth for low- and middle-income families. Globalisation and automation have weakened the position of workers and their ability to secure a decent wage. The financial crisis of 2008 only seemed to increase the isolation of corporations and elites, who often appear to live by a different set of rules than ordinary citizens. ${ }^{29}$

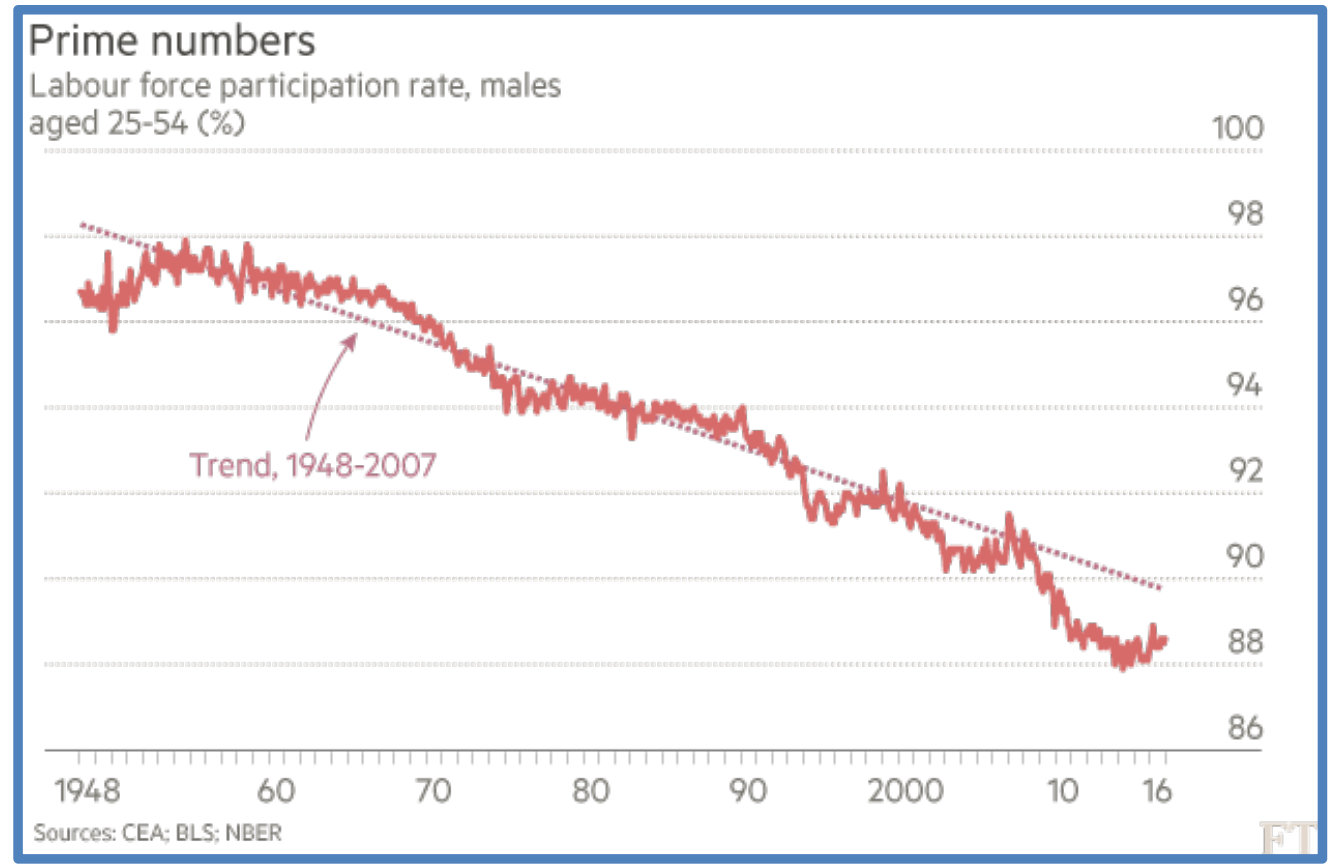

Figure 9: Labour force participation rate, males (USA) 
In Europe, we are used to thinking that the US labour market is flexible, and that it is easy to find a new job. However, there is now evidence that that does not hold anymore. The diagram above brings a new and trublesome story. The participation in the labour force of prime-aged males (25 to 54) has been on a 70-year downward trend, while that of prime-aged females has flatlined for three decades. This is a poor performance by the standards of most high-income economies. It is impossible to argue credibly that this is the result of particularly generous US welfare benefits or particularly high minimum wages. The failure is deeper. This is more a sign that there is a lack of upskilling and brigdes back to work. These facts about the employment situation for prime age males might be one element behind the discontent ${ }^{30}$. Jobs for the boys is just half the story in America, according to Sara O'Connor in the FT ${ }^{31}$. Female participation has stagnated or fallen beween 2000 and 2015: Only in seven of 35 OECDcountries has prime age female participation declined over this period, the US among them. What explains the fact American women diverged from the global trend? Some of the reasons will be the same as for men. Add to that that US policy is also particular unsupportive of women who want to stay in work when they have children, with the result that many drop out. In the rest of the world, policy is moving in the opposite way. Take paid parental leave. The average length of paid leave available to mothers across the OECD countries has increased from 17 weeks in 1970 to just over a year. In the US, it was 0 in 1970 and remains zero to this day.

However, much of this discontent is driven by anger that is not fundamentally economic. There are strong anti-immigrant, anti-Mexican, anti-Muslim and anti-refugee sentiments. In the primary elections the story was almost entirely about racial resentment. Researchers ${ }^{32}$ have found that support for Trump in the primaries strongly correlated with respondents' racial resentment. Republican voters with the lowest opinions of Muslims were the most likely to vote for Trump, and voters who strongly support mass deportation of undocumented immigrants were likelier to support him in the primaries.

Edward Luce wrote in Financial Times about the historical conflict between white and black people in the American working class: "It would be difficult to read America's history: or decode the 2016 presidential election, without reference to the struggle between poor whites and the descendants of former slaves..... The idea that poor whites will forge an economic coalition with poor blacks and up-end US politics is as far from reality as ever.”33

A counterbalance is the fact that the Democrats' strongest groups of voters: Ethnic minorities, unmarried women and young Americans under 30, are more numerous than ever. In Obama's victory in 2008, these groups constituted 51 percent of the general voters. Now, these groups constitute 63 percent, although it was not enough to give Hillary Clinton a majority of the electoral votes. American popular opinion has, between 2001 and 2015, strongly moved towards liberal, progressive and tolerant values in all of 16 major valuebased issues, involving LGBT-rights, acceptance of abortion and extramarital children. The liberal position in these questions have reached an "all time high level”, according to Gallup.

However, a more depressing interpretation of the US political development was presented during the American election campaign by Simon Schama, a contributing editor, in the Financial Times. He wrote that: 
"... unexpectedly to those living in the eco chamber of broad sheet news and policy seminars ... something altogether outside the norms ... has risen from history's tomb: The cult of the pure national tribe is back with a vengeance. It stalks the globe, from eastern Europe to the crypto-facist "alt right". The world now divides into those who wish to live only with the people who look, sound and pray like them, and those who live, in fact celebrate, heterogeneity, the marketplace of the modern city." ${ }^{34}$

The Swedish political scientist Bo Rothstein ${ }^{35}$ is of the opinion that perceptions of corruption as favouritism may have delivered Trump the Presidency. "First, one of the most surprising pieces of data that I have come across is that most white Americans perceive that discrimination against whites is now a bigger problem than that against blacks or Latinos. As I see it, this has nothing to do with reality but when people decide whom to vote for, it is perceptions that count. And, as has been forcefully argued by Mark Lilla, much of the politics from the liberal left in the US, including Hillary Clinton, has been focused on what is known as "identity politics":

"In practice, this has resulted in targeted policies to women and various minority groups such as affirmative action and quotas to jobs and education. Instead of focusing on universal programmes for all or very broad segments of the population, the Democrats and Clinton came to represent policies seen as favouritism ("corruption") towards minority groups by the white male working class. Targeted programmes are also very vulnerable to suspicion about malpractice in implementation processes because decisions about individual cases are often very complicated (who is eligible and how much preferential treatment is justified). Universal programmes, once the hallmark of successful leftist policies, do not suffer from this problem usually”.

The final result showed Hillary Clinton as a winner of the popular vote with 65.840 .000 votes against 62.980.000 for Donald Trump. Clinton performed better then Trump among young people up to 45, while Trump got a majority among voters older then 45 . Clinton won by women, 54 versus 41 and Trump among men, 52-41 ${ }^{36}$.Hovewer, Trump secured 306 of the electoral college votes, while Clinton received 232. White voters, male and voters over the age of 45 , secured the victory of the electoral votes for Trump.

Far from being purely a revolt by poorer whites left behind by globalization: Yes, they did indeed turn out in greater numbers for the Republican candidate than in 2012, Trump's victory also relied on the support of the middle-class, the better-educated and the well-off, the traditional Republican voters. Most those Americans who earn less than $\$ 50,000$ a year, one in three Americans, voted for Clinton. Most of those who earn more backed Trump. ${ }^{37}$

\section{Trumponomics - what does it mean?}

Donald Trump's inauguration address was a continuation of his election campaign, not a way of bridging the gap between Republicans and Democrats. “Make America Great again”, was the lead theme of a neo-nationalistic and protectionist speech: 
"Every decision on trade, on taxes, on immigration, on foreign affairs will be made to benefit American workers and American families. We must protect our borders from the ravages of other countries making our products, stealing our companies, and destroying our jobs. America will start winning again, winning like never before. We will bring back our jobs. We will bring back our borders. We will bring back our wealth. And we will bring back our dreams. We will build new roads and highways and bridges and airports and tunnels and railways all across our wonderful nation. We will get our people off of welfare and back to work,rebuilding our country with American hands and American labour.... We will follow two simple rules: Buy American and hire American.”

What will trumponomics mean for the global economy? Anatole Kaletsky, an UK economist, journalist and author, chairman of the Institute for New Economic Thinking, has published an overview "Trumping Capitalism” of opinions from leading economists like Stiglitz, Simon Johnson, MIT, Martin Feldstein, Edmund Phelps, Robert Skidelsky, Dani Rodrik and Kenneth $\operatorname{Rogoff}^{38}$. He asks whether Trump's victory “marks the end of a period of post-crisis confusion, when the economic model that failed in 2008 was finally recognised as irretrievably broken, and the start of a new phase of global capitalism, when a new approach to economic management gradually evolves”?

"If history is any guide, the near-collapse of the global financial system in 2008 was always likely to be reflected, after a lag of five years or so, in challenges to existing political institutions and prevailing economic ideology.... this was the sequence of events that followed previous systemic crises of global capitalism ..... Keynesianism followed the Great Depression of the 1930s; and Thatcher-Reagan market fundamentalism followed the Great Inflation of the 1970s. Could Trumpism - understood as a lagged response to the 2008 crisis - herald the emergence of a new capitalist regime?"

This question can be divided into three parts, according to Kaletsky: Can Trump's economic policies work? Will his administration's economic program be politically sustainable? And what impact might Trumpism have on economic thinking and attitudes to capitalism around the world?

The opinions of leading economists are mixed, some are highly critial, for example Stiglitz, who thinks that "The only way Trump will square his promises of higher infrastructure and defence spending with large tax cuts and deficit reduction is a heavy dose of what used to be called voodoo economics.” For Stiglitz, Trump represents a re-enactment of the Reagan era's socially regressive trickle-down economics, but with the addition of two further lethal ingredients: A trade war with China and a loss of access to health care for millions.

Simon Johnson, MIT and the Peterson Institute for International Economics is also highly critical: "Trump seems determined to lower income taxes for high-income Americans, as well as to reduce capital-gains tax (mostly paid by the well-off) and nearly eliminate corporate taxes (again, disproportionately benefiting the richest)." Johnson notes that Trump leads "a coalition of business people who wrongly believe that protectionism is a good way to help the economy”, and “market fundamentalists" who are determined to cut taxes. To consolidate this 
coalition, the market fundamentalists are embracing protectionism, justifying Trump's proposed import tariffs to pay for slashing corporate taxes. Tariffs, however, are equivalent to increasing the sales tax. Thus, the result will be to "deflect attention from the essentials of their policy: lower taxes for the oligarchs," paid for by "higher taxes: not to mention significant losses of high-paying jobs" (as a result of protectionism), "for almost everyone else”.

Others are more positive. The Keynesian economic historian Robert Skidelsky sees positive features in Trump's policy ideas, and even in his economic philosophy. “Trump's protectionism harks back to an older American tradition of a high-wage, job-rich manufacturing [economy that] has foundered with globalisation,” Skidelsky says, and even "Trump's isolationism is a populist way of saying that the US needs to withdraw from commitments which it has neither the power nor the will to honour”.

Most important of all, says Skidelsky, Trump’s proposal of an “\$800 billion-\$1 trillion program of infrastructure investment," a "massive corporate-tax cut," and "a pledge to maintain welfare entitlements" adds up to "a modern form of Keynesian fiscal policy." As such, Trumpism amounts to a "head-on challenge to the neoliberal obsession with deficits and debt reduction, and to reliance on quantitative easing as the sole, and now exhausted, demandmanagement tool.” In a similar vein, Kenneth Rogoff, argues that Trump's fiscal stimulus and emphasis on deregulation will boost demand in the classic Keynesian manner. While deregulation will not necessarily "improve the average American's wellbeing," and his tax proposals will "disproportionately benefit the rich," they could make the US economy "move significantly faster, at least for a while.”

Martin Feldstein, Harvard University, who served as Chairman of President Ronald Reagan's Council of Economic Advisers, welcomes the prospect of a reduction in top marginal tax rates. President Barack Obama's policies, Feldstein argues, continued an unhealthy "shift in the tax burden to those with the highest income levels" since the Reagan era. But while Feldstein favours broadening the tax base away from the richest Americans in a "revenueneutral way," he is sceptical about Trump's signature promises of higher wages, more "middle class" jobs, and stronger economic growth. The "economy has essentially reached full employment, with the unemployment rate at $4.9 \%$ in October," he notes. The tighter labour market has in turn caused consumer prices to "rise $2.2 \%$ over the past year, up from $1.9 \%$ a year earlier," while "production workers' wages rose $2.4 \%$.” Given real wage growth and rising inflation, he sees "no reason to seek an increase in aggregate demand at this time".

Kaletsky himself identified some economic benefits that could partly offset the obvious risks of higher interest rates, trade wars, an over-valued dollar, and the regressive distributional effects justifiably criticized by Stiglitz, Johnson and Rogoff. The most important are the promise of a strong Keynesian growth stimulus, an easing of over-zealous financial regulations that locked many households out of mortgage markets, and some sensible tax reforms, particularly those aimed at encouraging profit repatriation by US companies and broadening the tax base.

Kaletsky's own conclusion regarding a new global economic order is that "Trump represents a comprehensive rejection of the economic thinking that has dominated the world for a generation. Shaping the new economic thinking will be the most important challenge for both 
economists and politicians in the years ahead. In my view, the defining feature of each successive transformation of global capitalism has been a shift in the boundary between economics and politics, and between faith in market forces and reliance on government intervention.”

He quotes Yoon Young-kwan, a former South Korean foreign minister, who describes "the empty room" as an "interregnum": "We are at an interregnum. Populism, nationalism, and xenophobia float on the surface of a larger sea change: a fundamental shift worldwide in the relationship between the state and the market.” Reconciling these two domains of activity "is the central concern of political economy today, just as it was for Adam Smith in the eighteenth century, Friedrich List and Karl Marx in the nineteenth century, and John Maynard Keynes and Friedrich von Hayek in their long debate on the topic through the middle decades of the twentieth century." Yoon adds that Trump is merely the most acute symptom of a global phenomenon: "Social and political discontent will continue to bubble up around the world until we return the state-market relationship to a healthy equilibrium.”

Kaletsky has no big expectations of "trumponomics": "Under Trump, US economic policies in the next four years are very unlikely to provide the right answer; but his administration may at least show the world what not to do.”

\section{The UK paradoxes}

The referendum in the UK was meant to put an end to an internal conflict in the Conservative party, between a retrospective elite, dreaming of the resurrection of a British Empire 2.0, and on the other side the elites that will see the UK in a leading role in Europe: "To understand the situation the UK has got itself into, it helps to know that Brexit isn't simply an anti-elitist revolt. Rather, it is an anti-elitist revolt led by an elite: a coup by one set of public schoolboys against another."39

The paradox was that one of the two, Pro-Brexit, succeeded in channelling the discontent within the working and middle classes, with the economic and social decline, into a criticism, not of the Conservative government's austerity policies and reverse redistribution policies, but rather of the EU and the UK membership of the EU.

According to a McKinsey's report "Poorer than their Parents?” 70 percent of income earners in the UK have had stagnant or falling income during the last twelve years, still after tax and transfers up to 60 percent had stagnant or falling income. This is due to the fact that these systems have changed in order to favor the conservative core voters. The social security system that is supposed to ensure safety in times of change has become less effective. "In the UK, income inequality .....is almost the highest in the European Union”. ${ }^{40}$

The UK referendum on membership of EU is the most dramatic expression of how economic and social conditions have had political effects. The result was far beyond expectations. There are however additional economic and social conditions that determine how to vote in the UK and the US writes David Aaronovitch in The Times: 
"Donald Trump is not a hero of "the left behind", he is actually a white nationalist. He is champion of the resentful white population that used to be able to fly the Dixie flag, call blacks "lazy" and Jews "money-grubbing" and always knew that there was someone, somewhere who was inferior to them. It's different in Britain of course. But in speaking to Leave voters ... . I have been struck by two things: the first is belief in a return to a Britishness and a Britain that had been more separate, more exclusive and more cohesive in the past. And the second is resentment. Of the rich, ... of London, of southerners and of foreigners who are changing things just by being around and speaking languages other than English. Not all Leave voters, by any means, but quite a few." ${ }^{41}$

However, the socio-economic background of the Brexit is complicated. Most populist voters are neither poor nor unemployed; they are not victims of globalisation, immigration, and free trade. The main demographic groups behind the anti-establishment upsurge have been people outside the workforce: Pensioners, middle-aged homemakers, and men with low educational qualifications receiving disability payments, according to Anatole Kaletsky ${ }^{42}$.

He points at detailed analyses of the votes actually cast in the Brexit referendum, showing that the group most directly affected by low-wage competition from immigrants and Chinese imports, young people under 35, voted against Brexit by a wide margin, $65 \%$ to $35 \%$. Meanwhile, $60 \%$ of pensioners who voted, backed the "Leave" campaign, as did $59 \%$ of voters with disabilities. By contrast, $53 \%$ of full-time workers who participated wanted Britain to remain in Europe, as did 51\% of part-time workers. The British data suggest that cultural and ethnic attitudes, not direct economic motivations, are the real distinguishing features of anti-globalisation voting. Asked whether "social liberalism" is a "force for good" or a "force for ill," $87 \%$ of "Remain" voters said it was a force for good, while $53 \%$ of Leave voters called liberalism a "force for ill." On "multiculturalism," the difference was even starker: 65\% of Leave voters were against it, while $86 \%$ of Remainers approved. Another analysis, published by the BBC after the referendum, found one of the strongest predictors of a Leave vote to be support for capital punishment!

It seems, therefore, according to Kaletsky, that the conflicts generally ascribed to economic grievances and globalisation are actually the latest battles in the culture wars that have split Western societies since the late 1960s. The main relevance of economics is that the 2008 financial crisis created conditions for a political backlash by older, more conservative voters, who have been losing the cultural battles over race, gender, and social identity.

Anatole Kaletsky concludes that the dominance of free-market ideology before the crisis allowed many controversial social changes, ranging from income inequality and intensified wage competition to greater gender equality and affirmative action, to go almost unchallenged. "Progressive" social liberalism and "conservative" free-market economics seemed to be two sides of the same coin. But when free-market economic liberalism failed in the 2008 crisis, political challenges to social liberalism could no longer be deflected by invoking impersonal economic laws.

Political commentators now admit that Brexit "has unleashed a dynamic that none of us quite understood”. An analysis by the British Election Study in October revealed that people identified more strongly with how they voted in the EU referendum than a political party. The 
researcher warned that "this new cleavage could yet disrupt British politics". "The EU referendum revealed a more fundamental divide,” according to Chris Prosser, of Manchester University $^{43}$.

Another paradox is the political rhetoric, that the new UK Prime Minister Theresa May has been using since her first day in office. She talks about politics for the many, not just the few, a message that runs in total contrast to the politics that the Tory party has run for decades: "She has castigated overpaid corporate bosses, called for workers representation on company boards, imposed stricter controls on foreign investment in strategic sectors of the economy and emphasised the role of government in shaping the economic landscape. What the prime minister is looking for is a new social contract in which big business acknowledges a wider set of responsibilities." 44

This reversal is illustrated by the Tory government engaging the former head of Tony Blair's policy unit to undertake a "review of modern employment", which will address concerns that millions are stuck in insecure and stressful work. ${ }^{45}$ In her Brexit-speech to the Parliament, January 17, 2017, Theresa May gave a new confirmation on her commitments to protect workers' right:
"And a fairer Britain is a country that protects and enhances the rights people have at work. That is why, as we translate the body of European law into our domestic regulations, we will ensure that workers' rights are fully protected and maintained. Indeed, under my leadership, not only will the government protect the rights of workers set out in European legislation, we will build on them. Because under this government, we will make sure legal protection for workers keeps pace with the changing labour market: and that the voices of workers are heard by the boards of publicly-listed companies for the first time.”

Martin Wolf has in Financial Times described this as a "burial" of Thatcherism: " Theresa May has buried Thatcherism. Under a Conservative government, the UK is now embracing the political ideas of fairness and government intervention ... Mrs May's rhetoric marks a huge shift. Its impact depends on just how those words become reality." In the beginning of 2017, Prime Minister May launched a new concept, "the shared society". The Times presented it as a way of ditching Margaret Thatcher's and David Cameron's approach to social policy as she pledges to create a "shared society" where the state helps to strengthen communities $^{46}$.

However, prospects for the next few years are quite different.“The picture is one of overall stagnation, plus rising inequality and pensioners, who have done far better than people of working age in recent years will continue do so", according to Martin Wolf, commenting on a report from the Office for Budget Responsibility ${ }^{47}$. Median real disposal incomes will increase by 7 per cent for those of the top half of the distribution, and those of the bottom half will shrink by 2 per cent. This dark picture for working people is confirmed by a study made by the Resolution Foundation, a think-tank, which reveals a country that is to give priority to the well-off over the poor. Young women are seeing a lack of generational pay progress, and they are only catching-up with their male counterparts because of a deterioration in outcomes for young men ${ }^{48}$. 
Another paradox is the shift in the arguments for leaving the EU. For a long time, the argument was about getting rid of European legislation and bringing back the power to the British Parliament. However, during the referendum campaign, it was immigration that was the main focus," take back control of our borders". This has now become more important than guaranteeing British business access to the European market. Prime Minister May wants to present the UK as an open society, and wants the UK to be seen as a global leader of free trade. The rhetoric however, has quickly lost its credibility when she and her ministers launched one proposal after another about how the UK will close the borders for workers from Europe, eg. "naming and shaming companies with "international staff on their books", a proposal that, however, was withdrawn. The xenophobic forces are growing stronger. It is an insecure, introverted "Little England" that is emerging behind the grandiose global rhetoric "The government has yet to grasp a simple fact on globalisation: Nations cannot declare themselves open for business and then close the doors to foreigners". ${ }^{49}$

These paradoxes: Brexit and a new social contract, should be viewed in the light of managing the politial landscape, on the one side the threat from the right wing, UKIP, and on the other side from the opposition Labour party. It is a dangerous game, and it requires that the government is able to stick together, and that the entire Conservative party submits to Brexit, even in times of economic hardship, and presents a quite new UK social policy.

These hardships are now underway. UK has always maintained the argument that the British economic model with so-called "flexible markets", is superior to models in continental Europe, for example Germany and France. The facts, however, contradict the British selfimage. The declining value of the British pound, by 15-20 percent (depending on which currency one is comparing with), is the most visible indication. The overall effect of depreciation on this scale is to reduce real national income and overall living standards: The cost of imports is increased and export prices are lowered ${ }^{50}$.

Underlying this is a weak development of productivity, which was recently confirmed in a report from the National Office of Statistics ${ }^{51}$. Output per hour in the UK was 18 percentage points below the average for the rest of the major G7 advanced economies in 2014: The widest productivity gap since comparable estimates began in 1991. Thus, it is in this state of weakness the UK is supposed to cast off from the world's largest market, the single European market, seeking a role outside Europe on a whole range of smaller markets, not knowing what conditions should apply for British business.

Prime Minister May's official visit to the US at the end of January to meet President Trump highlighted this situationen. In The Guardian, Jonathan Freedland described the relations between the US President and the UK Prime Minister in the following way ${ }^{52}$ :

"He (Trump) will have seen May as that most desperate of creatures: the housebuyer who rashly sold her old house before she had found a new one. Having tossed away Britain's keys to the European single market, she will soon be homeless: and Trump knows it. For all the niceties: May's shrewd deployment of a royal invitation for a state visit and her compliment to the president on his "stunning election victory", flattery which saw Trump glow a brighter shade of orange: he will have seen May as a sucker who needs to make a deal. And he will look forward to naming his price. 
What would such a deal look like? Tariffs between the US and the UK are already low, so it is the dropping of a different kind of barrier that Trump would be after. That could be a softening of the food standards that have kept out hormone-injected US beef. Or granting access to the NHS to overcharging US drug companies. Or a relaxation in environmental or labour rules that, set with our onetime EU partners, proved too onerous for US firms until now.

When Trump demands all that, May, needing a deal, any deal, to prove that Brexit is not a disaster, will struggle to say no. And what would be gained? One study, released on Friday, estimated that leaving the single market would bring a loss in UK trade of up to 30\%: while a new deal with the US might boost it by a meagre $2 \%$. It was a reminder that while the US might be a bigger market for British exports than any other single country, it is dwarfed by the European continent on our doorstep."

At the same time, more and more signals that international companies, that have operations in the UK, are hesitant in continuing to invest in the country and even withdraw. For instance, the Japanese government has submitted a report to the UK Government warning that Japanese companies will move to continental Europe if the UK cannot guarantee access to the internal market; today these big Japanese corporations make half of their European investments in the UK. Furthermore, UK banks, are planning to move part of their operations from London to Frankfurt, Paris and other capitals. How will this end?

The EU paradox: Why has it gone so bad for the EU?

Europe is the continent of many nations, all with strong traditions and cultures. The EU was created to foster peace and stability between old enemies via economic integration. The EU has been so successful that the original six members have now become 28 (before Brexit), and more countries wish to join; 19 member countries have adopted a common currency. However, this success story came to a brutal end, when the anglo-american banking crisis hit Europe. The EMU-countries had to manage the economic effects on currency, business and labor market. What followed was a euro-crisis, economic stagnation, lack of investments, increasing unemployment and devaluation of the social systems. 


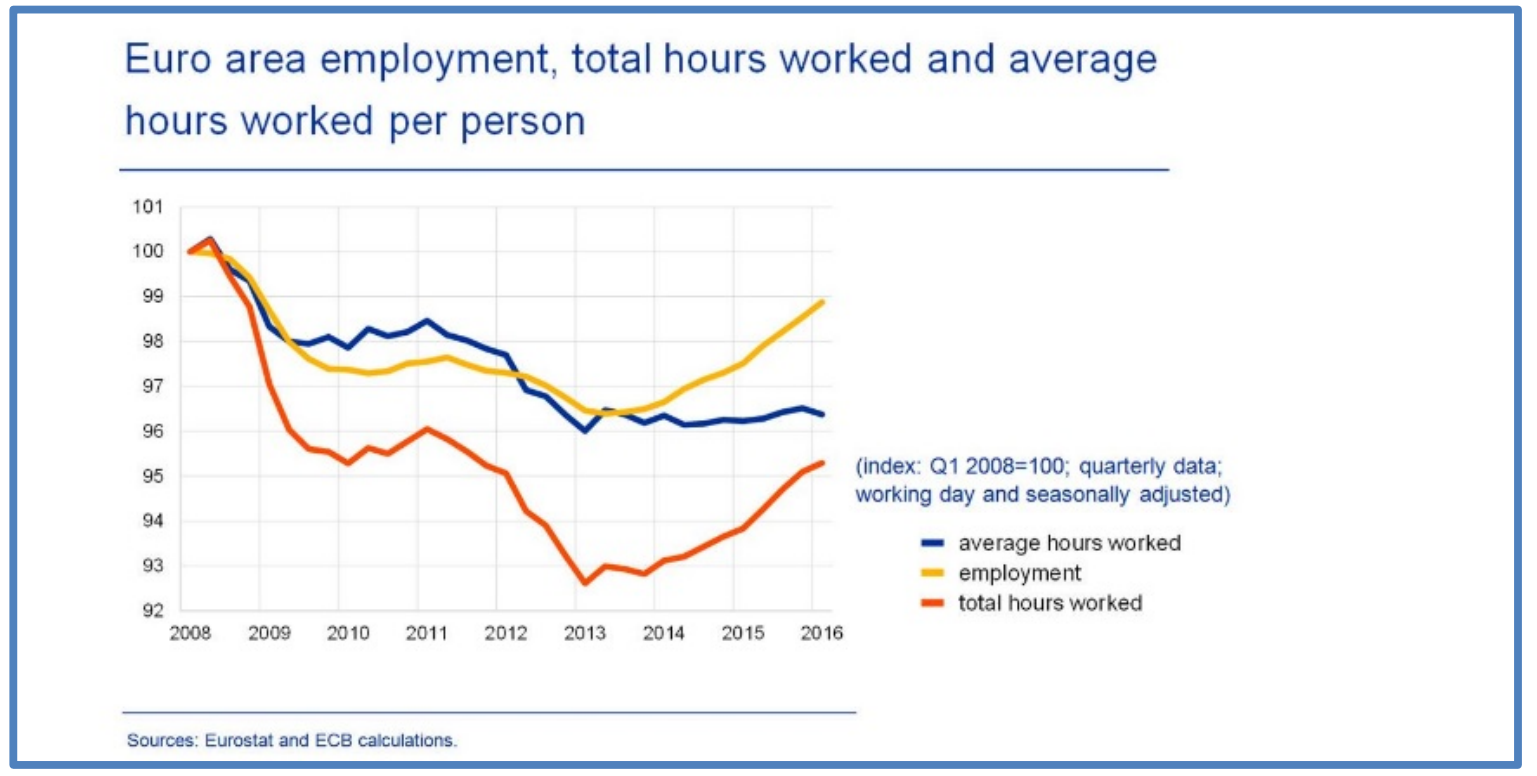

Figure 10: Euro area employment

This diagram shows that Europe was hit by a double recession. It illustrates employment, total hours worked and average hours worked per person ${ }^{53}$. The red line illustrated hours worked, underlining how the double recession has hit employment, first the financial crisis 2007-2008 and then the euro-crisis 2011-13. In 2015, employment was still 5 per cent under the precrisis level. How can we explain that the EU, with the largest internal market with 500 million consumers and the world's most ambitious welfare system, have been unable to handle crisis in a better way? How can we give a reasonable answer to this "inconvenient question"?

Here is some food for thought. The European Central Bank (ECB) in 2010, effectively put a stop to the fragile recovery by raising rates and discouraging investors. Once the general demand from consumers and investors held back because of uncertainty, the EU recommended member countries to further restrain demand through austerity policies to achieve "fiscal consolidation". The result was the opposite: Weak growth and increasing debt. Between 2010 and 2014, the debt ratio increased in the EU from 78.5 percent to 87 percent of GDP. ${ }^{54}$

GDP per capita was 26,200 euros in 2008, still the same in 2015- seven lost years! At the same time, a substantial and growing current account surplus was built up, a financial saving that was not invested in Europe and therefore had to be invested outside Europe, in deficit countries like the US. It was mainly Germany and northern Europe; the Netherlands, Denmark and Sweden, that were responsible for this particular policy. ${ }^{55}$

Some hold the construction of EMU responsible for the economic stagnation, and claim that the weakness is due to EMU being an incomplete project, and that it now needs institutional reforms, completion of EMU. Lord Turner argues ${ }^{56}$ that a "Japan-style lost decade" is probably inevitable, and that it requires both short term and long term measures to avoid it. If those measures cannot be executed, it would be better to dissociate the euro-co-operation, preferably by having strong countries like Germany leaving the co-operation.

Some argue that the current policy is inadequate, but not the construction of the EMU as such. Martin Sandbu of Financial Times argues that the reason for EMU being in such a miserable 
state can be explained by policy mistakes due to German hegemony. He argues that the financial bubble in Europe was created by German banks who lent the German surplus to borrowers in southern Europe, who could use the money for real estate investment and consumption, instead of improving productivity and real incomes. His conclusion is that it would be wrong to break up the EMU. ${ }^{57}$

In The Five Presidents Report (2015) ${ }^{58}$, the EU leadership officially stated their position. They presented a proposal for a first and second step to reform the EMU. The plan will be presented in a White Paper on the Future of the European Union in March 2017, implemented thereafter and completed in 2025. That plan involves extensive institutional changes with common fiscal policy and a euro-parliament, changes that will have to be submitted to citizens in referenda in one country after another.

Martin Sandbu's standpoint regarding policy failures is supported in an analysis, published by the ECB in October 2016. The author asked: Why is investment in the euro area so low compared to the US experience? This question matters because of the importance of investment for long-term growth potential. Understanding the causes of low investment is crucial for helping policymakers to decide on the right remedy. ${ }^{59}$

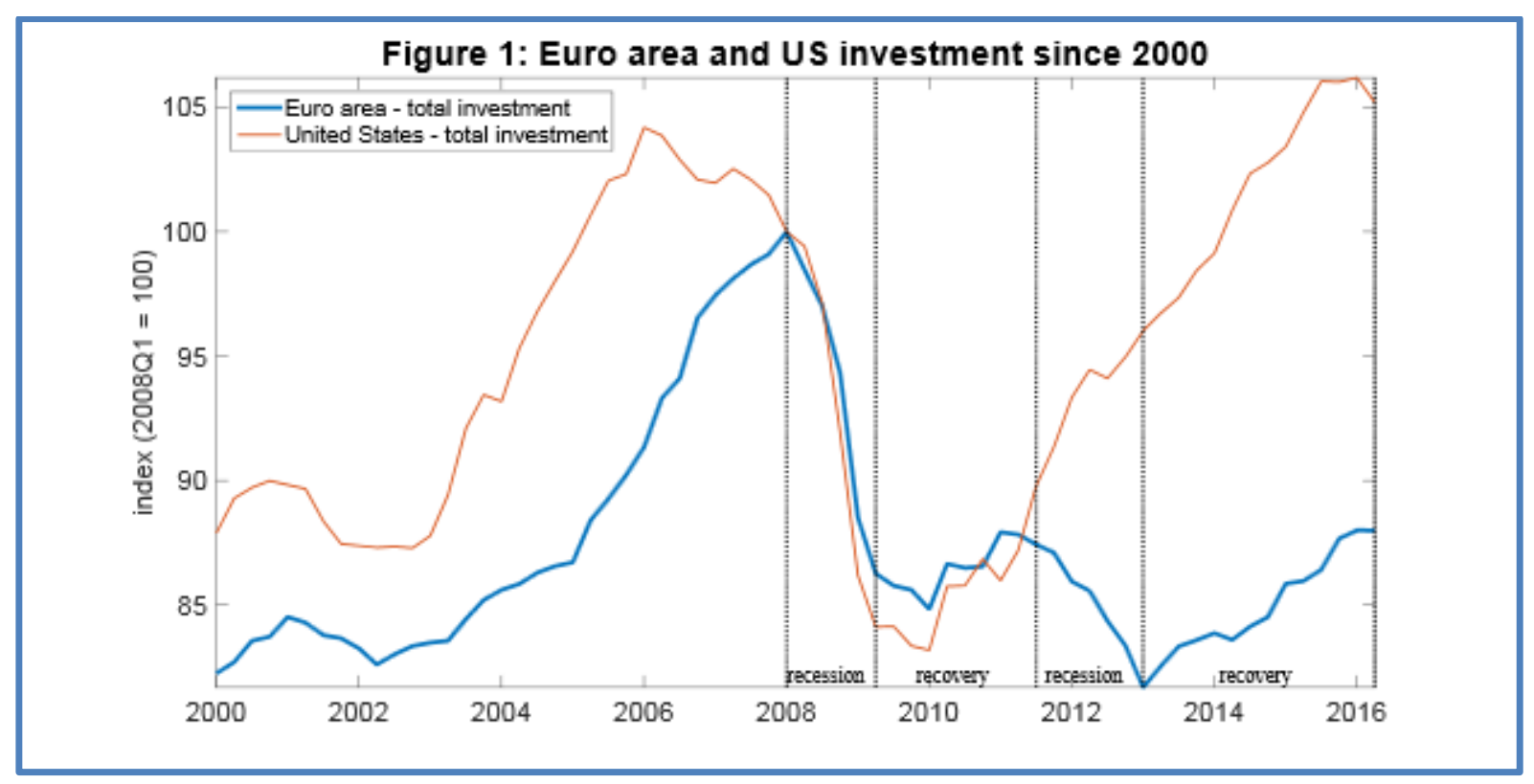

Figure 11: Investment Euro area and USA

The figure shows that the decline in investment during the Great Recession was roughly comparable across the two monetary areas. Their speed of recovery was also comparable until 2010. With the intensification of the euro area sovereign debt crisis in 2011, however, the recovery in euro area investment came to a halt. The euro area fell into a recession, which lasted from the third quarter of 2011 to the first of 2013. Real investment fell again, to an even lower trough than during the Great Recession. While euro area investment remains well below its pre-crisis peak, US investment has been growing strongly ever since 2010 and now exceeds the pre-crisis levels. 
Two factors make developments in euro area investment since 2011 unusual, and set it apart from the United States. The first is the onset of the sovereign debt crisis, which tightened lending conditions in stressed countries, led to tighter fiscal policies and elevated uncertainty, which ultimately triggered a new euro area recession. Historically, two consecutive recessions within such a short interval of time was unprecedented in the euro area. The second factor is the different developments in investment in construction. This has been much slower to pick up in the euro area, compared to the United States. While euro area non-construction investment has started to recover slowly in recent quarters, the dynamics of investment in construction eight years after the Great Recession, essentially remain flat. By contrast, US investment in construction started growing again at the beginning of 2011, although, as of the second quarter of 2016, it was still 10\% below the level of the fourth quarter of 2007. Furthermore, euro area construction investment has contributed much less to the recovery in investment than in the United States and as of the second quarter of 2016, it stood 21\% below the level of the first quarter of 2008.

The conclusion is, according to the ECB, that the investment performance in the current cyclical phase is not the most disconcerting component of growth; rather, from a historical perspective, it is aggregate consumption that has been growing more slowly than usual. This finding is important for policymakers. The current recovery in investment can only be sustained if aggregate consumption also grows at a sufficiently robust pace in parallel. Policymakers would be misguided to focus on investment exclusively. Instead, policies should aim for a broader recovery of aggregate demand and consumption in particular, according to ECB.

\section{The Swedish paradox}

The Swedish paradox is quite different. It consists of, on the one hand, a popular opinion arguing that Sweden is heading in the wrong direction, and on the other, a series of indicators, showing that Sweden is performing well in many respects in international comparisons.

According to a survey commissioned by Aftonbladet ${ }^{60}$, a Swedish newspaper, 60 percent of the respondents are of the opinion that Sweden is heading in the wrong direction. Merely 21 percent of the respondents consider Sweden to be heading in the right direction. When asked about the areas in which Sweden is heading in the wrong path, the replies were areas such as employment, integration, taxes, foreign aid, law and order and healthcare. The only exception was the environment.

The paradox is that Sweden in international comparisons holds a leading position in a number of areas. This includes areas such as competitiveness ${ }^{61}$, innovation ${ }^{62}$, sustainable development63, gender equality ${ }^{64}$ and in an overall index "Good Country Index," which ranked 163 countries by their contributions to the global community, Sweden takes the top spot overall. In individual categories, the Nordic countries scored first in measures of Prosperity \& Equality and Health \& Wellbeing ${ }^{65}$. "Sweden must be bored of coming top in every bloody country index but that's the fact of the matter," says Simon Anholt, an independent policy advisor and the Index's creator, in The Local. ${ }^{66}$ 
The OECD's Sweden Economic Survey 2017 presents a deep analysis of the Swedish economy including income distribution ${ }^{67}$. OECDs notes that Sweden is an egalitarian society in international comparison, and has managed to combine equity with economic efficiency. However, inequality has risen during the last ten years. It rose from an historical low in the 1980s partly stemming from ageing, changing family structures and migration. Living standards has increased for all groups, but social benefits rose less than earned income. Incomes of newly-arrived immigrants and single mothers trailed the median. Public policies as regards unemployment insurance and other changes in the welfare system has played an important role.

Below, three graphs illustrating development of real income since 1970, the incidence of material deprevation and the relation between income development and purchasing power.

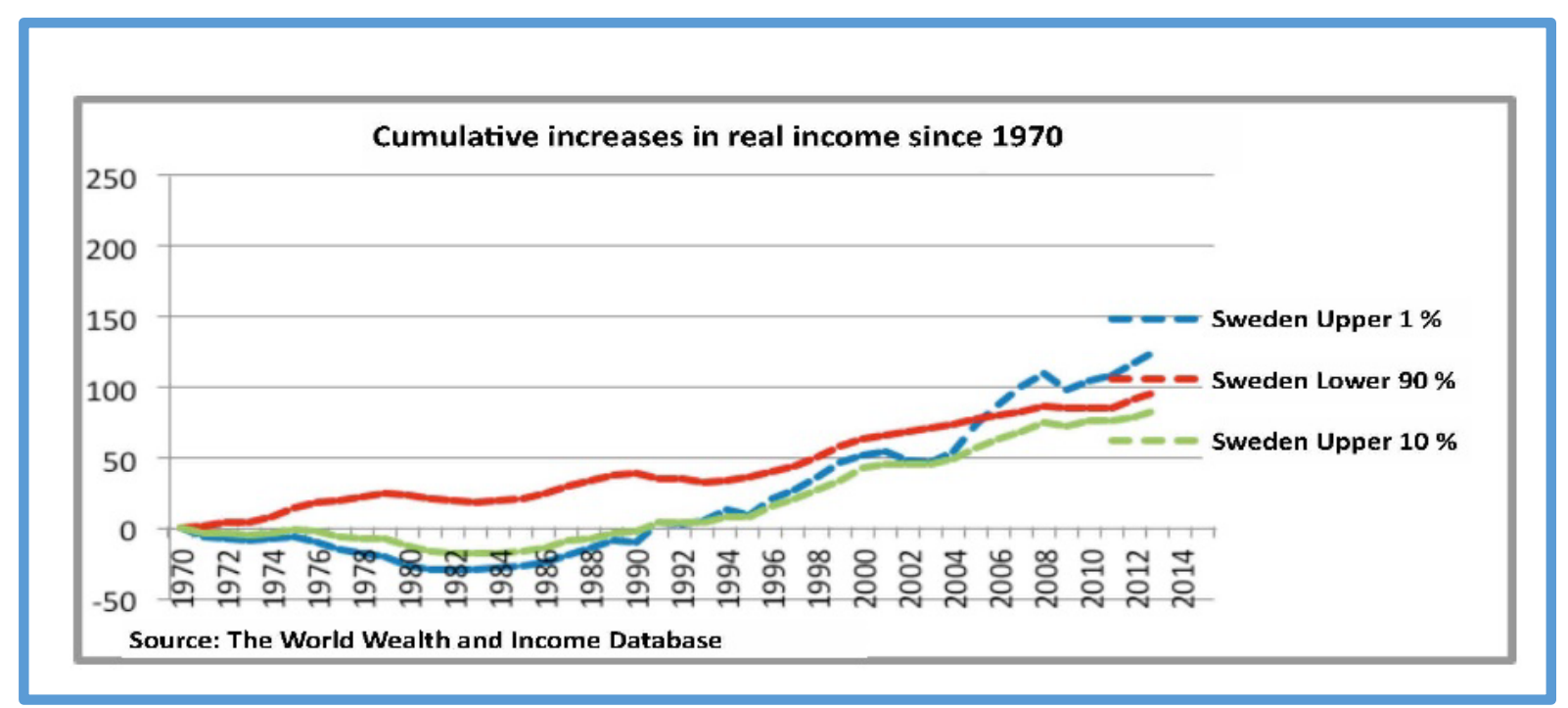

Figure 12: Increases in real income, Sweden

Income dstribution is different than in many other countries, apart from the last ten years when the top income earners have increased more than other groups. 
Figure 1.7. The incidence of material deprivation is low in Sweden In $2015^{1}$

\section{A. Material deprivation rate}

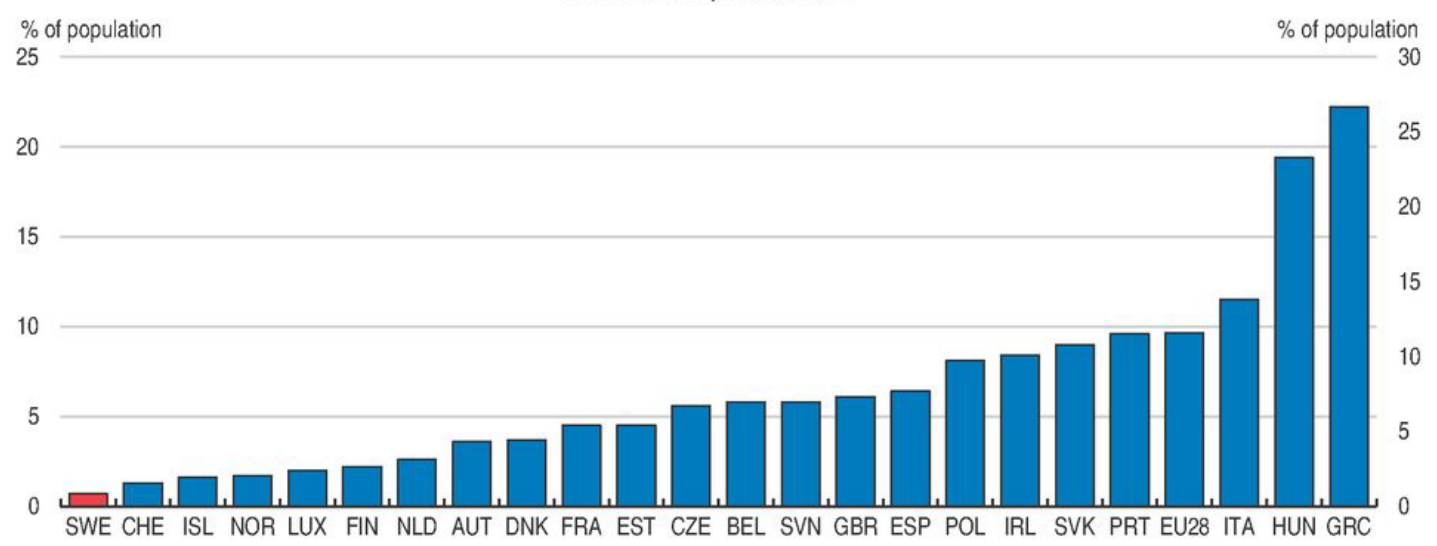

Figure 13: Material deprivation rate

While income inequality has risen over the last ten years, poverty and material deprivation is low in Sweden.

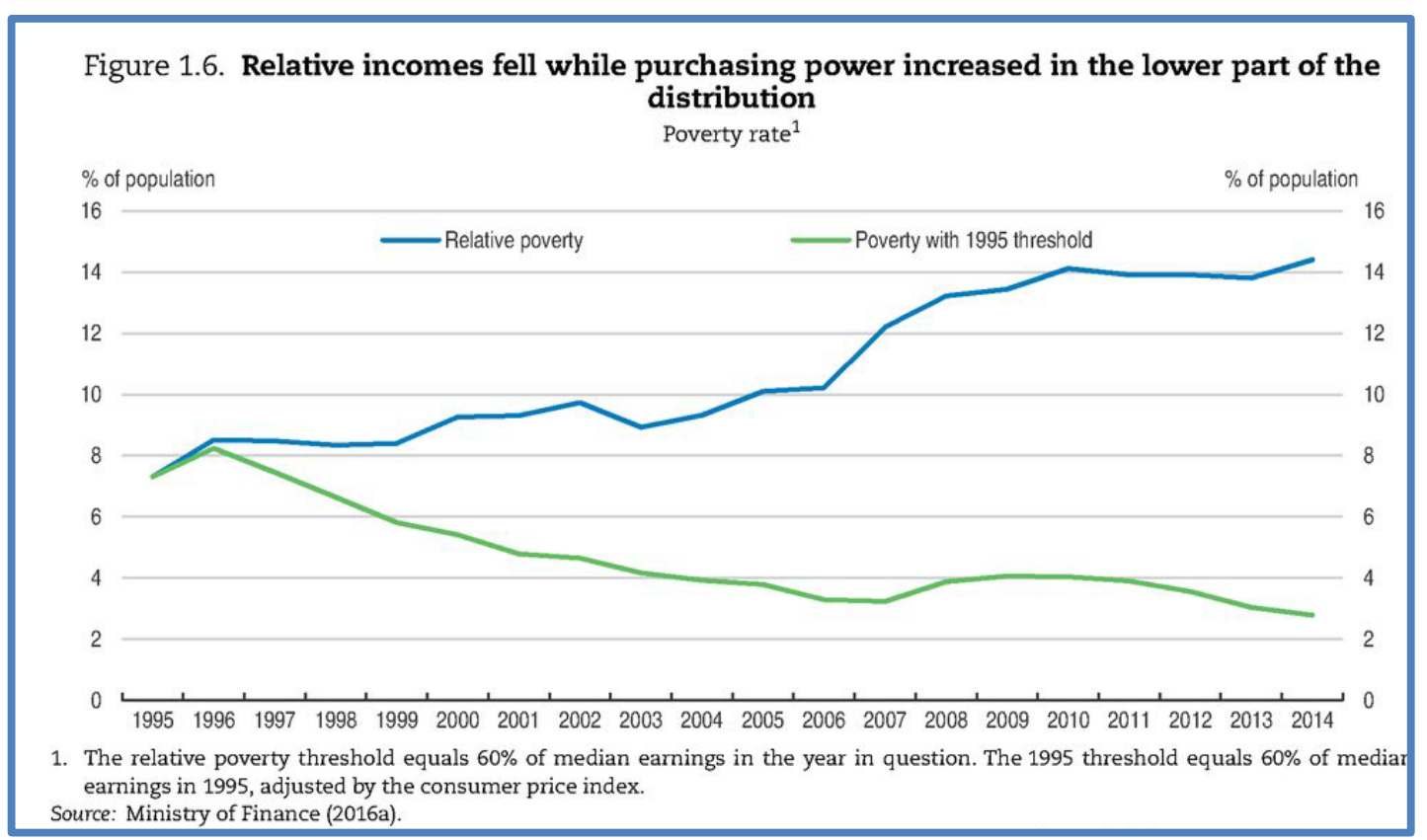

Figure 14: Poverty rate, Sweden

The above graph illustrates two way of measuring relativ poverty, the blue line 60 per cent of media earning, the green line 60 per cent of media earning adjusted by the consumer price index. Another paradox is that Sweden, despite the major refugee influx in the last couple of 
years and harsher political climate, remains one of the countries in the EU that has the most positive attitudes towards immigration, both from other EU countries as well as from countries outside the EU. Sweden has, according to Eurobarometern from May 2016, the highest portion of people who consider immigrants to contribute substantially to the country, more than four out of five people hold this opinion. Similarly, In Sweden 93 percent of the population think that the country should help refugees. 62 percent of Swedes consider immigration from countries outside EU as something positive. It is the largest percentage of positives in all of the EU. Compared to the last survey in November 2015, the proportion of Swedes with a positive outlook on non-European immigration decreased by eight percentage points, which is the highest decrease. Swedes also have a positive attitude towards immigration from other EU countries. Nearly four out of five agree on this, only Luxembourgers are more positive. ${ }^{6}$

\section{Fear not values: Fear of globalisation}

When the economy becomes a zero-sum game, the labour market stagnates and the social conditions decline for large groups, the criticism intensifies against the most tangible expressions of globalisation, free trade and migration. This is why the resistance towards migration has emerged in Europe, regardless whether the flows of refugees come from the Middle East and Africa, or if it is migration between member countries of the EU. Strong national public opinions now want to come to terms with policies of austerity and migration, policies with which they identify with the EU.

In an analysis of the Transatlantic trade negotiations, TTIP, Elvire Fabry, Jaques Delors Institute, writes that the lack of effective redistributive policy explains the increasing distrust of free trade:
"The specialisation of economies has favoured gains in efficiency and a progressive reorientation of the European and American economies towards greater value-added production, as well as jobs in the service sector, which has now made Europeans the world's biggest exporters of services. But the fact that this job redistribution has insufficiently been accompanied by national and European measures to help workers in the most affected regions and industries, contributes to today's doubts over the benefits of free trade as a whole." ${ }^{\circ 9}$

The Economist forwarded the same message in an analysis of what may be called "drawbridge up" or "drawbridge down", that is to say, between those who would like to see a more closed economy, and those who would like to see a more open economy: ${ }^{70}$

"Many blame globalisation for their economic plight. Some are right. Although trade has made most countries and people better off, its rewards have been unevenly spread. For many blue-collar workers in rich countries, the benefits of cheaper, better goods have been outweighed by job losses in uncompetitive industries. For some formerly thriving industrial towns, the impact has been devastating. Economic insecurity makes other fears loom larger. Where good jobs are plentiful, few people blame immigrants or trade for their absence. Hence the divide between college-educated folk, who feel 
confident about their ability to cope with change, and the less-schooled, who do not."

It can be tempting to see the economic and social development at large as the reason for the success of the right-wing extremists in many EU member countries. Though recent studies have nuanced that assumption. Instead, they highlight changes in the social safety net, employment security and unemployment insurance as more precise explanations. Such a study has been conducted on behalf of ETUI, the European Trade Union Institute, titled "Why far right parties do well at times of crisis: The role of labour market institutions.",71

The researchers claim that the progress of the far right wing is not a result of external forces outside the reach of the decision makers. On the contrary, it is rather a result of conscious choices regarding labour market policy. Governments in a number of member countries have degraded the terms for the unemployment insurance and liberalized employment protection:

"As a result, the unemployed have seen their standard of living deteriorate, while a growing segment of the labour force now works on temporary contracts and workers on permanent contracts feel increasingly insecure... The irony is that it is precisely these policies, targeted at solving Europe's economic predicament, that have intensified political instability in many European countries. If we are right, the adoption of these policies increases the risks and costs of unemployment, which, in turn, makes the rise of the far right more likely."

A final observation on the deeper roots of discontent: The German Bertelsmann Foundation has conducted an opinion poll showing that fear of globalisation is the decisive factor behind demands for changes away from the political mainstream. Values play a minor role: The lower the level of education, the lower the income, and the older people are the more likely they are to see globalisation as a threat.

Moreover, those who feel close to populist parties are mainly motivated by fear of globalisation. This effect is particularly evident when it comes to right wing populist parties, but it is also present for left wing populist parties. For example: In Germany, 78 per cent of supporters of the right wing Alternative für Deutschland (AfD) fear globalisation. In France, 76 per cent of Front National (FN) voters fear globalisation. In Austria, 69 per cent of Freiheitliche Partei Österreichs (FPÖ) supporters fear globalisation. ${ }^{72}$

\section{After globalisation: What's next?}

What does the present wave of support for neo-nationalism mean for globalisation as we know it; for trade, foreign direct investment and for business strategies? There is vital discussion among economists and scholars on the nature of change, and whether the new wave will replace the economic and political paradigms of the past 30 years. Let us first take a look at some statistical information, touch upon the role of digitalisation and the new business models, before we return to the questions of globalisation in the future.

Stagnating trade, more restrictions, less liberalisation 
Starting with trade, we now know that the pace of globalisation has slowed down, and in some respects even gone back. During 18 month of 2015-2016 world trade stagnated, despite an increased global growth. Such a prolonged stagnation has never before occurred. Furthermore, the international stock trade has since 2007 decreased from 57 percent of global GDP to 36 percent in 2015. The inflow of Foreign Direct Investment (FDI) has been registered below the level of 3.3 percent of GDP recorded in 2007 . $^{73}$

Some people are of the opinion that globalisation is in reatreat, pointing out the economic development in Europe as a key reason for this ${ }^{74}$. Adding to this, an analysis conducted by the WTO of 1000 trade policy measures showed that only 30 percent of these aimed at liberalising trade while 70 percent could be construed as limitations on trade.

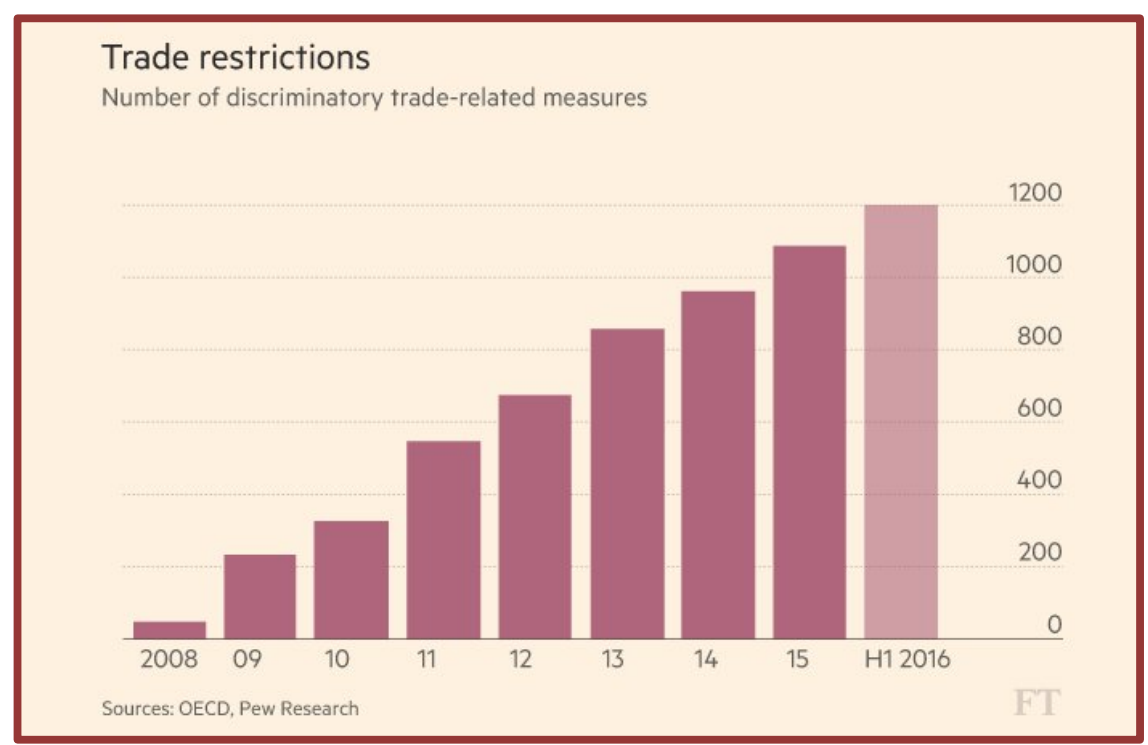

Figure 15: Trade restrictions

This FT-chart, based on statistics from OECD and Pew Research gives an illustration to how trade restrictions have grown in the aftermath of the financial crises.

We today run the risk of shifting from a rules-based trading system to one based on deals and power politics, according to Arancha Gonzales, Executive-Director, International Trade Centre $^{75}$. Some of the anti-trade sentiment is the result of rising wealth inequality and stagnating real wages. Policy and business elites did not speak frankly about the unequal distribution of benefits from trade, and failed to adequately accompany market-opening with good domestic policies to equip displaced workers to upskill, adjust and share in the new opportunities being created. Yet technological change is responsible for far more of the job losses than imports of goods and services: Trade has simply become a more identifiable scapegoat.

\section{Another side of globlisation: The digital economy}

Free trade, free movement of capital and foreign direct investment can be seen as one side of globalisation: Digital technological development has been a prerequisite for the emergence of 
global value chains. However, digitisation is at the same time an independent force that continues to transform business, the corporation and the working places in a way that transforms the social order that took shape during the industrial era. We are entering a " gig economy", a working life characterised by high degree of availability and flexibility, and high degree on uncertainty for the future, on jobs, on income and social security. The "uncertainty in times of change", which the new global division of labour has created, is reinforced when the traditional labour contract between a worker and an employer, a full-time job and a social security, is replaced with new flexible and digital platforms.

The German government has conducted an analysis of the new emerging order, a Green Paper with the title 'Re-imagining Work: Work 4.0 presenting the background and asking questions on what is about to happen, alongside a review on the social systems needed to handle the profound change of working life: ${ }^{76}$
"Work 4.0 will be more interconnected, digital and flexible. The specifics of what the future world of work will look like are still unclear. Since the beginning of the 21st century, we have been facing another fundamental transformation of production methods. The growing interconnectedness and rise in cooperation between man and machine is not only changing the way we produce things, but also leading to entirely new products and services. As a result of cultural and social shifts, new preferences are emerging with regard to work, and demand for products and services is also changing. What effects these developments will have on the organisation of work and social security is uncertain, but they can be shaped by society and policy- makers:- just as they could in the previous phases. We are at the beginning of new negotiation processes between individuals, the social partners and the state."

The US Government has made a similar exercise, focusing on Artificial Intelligence, AI. A report was published at the end of 2016, Artificial Intelligence, Automation, and the Economy ${ }^{77}$. The main message is that accelerating AI capabilities will enable automation of some tasks that have long required human labour: "These transformations will open up new opportunities for individuals, the economy, and society, but they will also disrupt the current livelihoods of millions of Americans."

There is substantial uncertainty about how strongly these effects will be felt, and how rapidly they will arrive. It is possible that AI will not have large, new effects on the economy, such that the coming years are subject to the same basic workforce trends seen in recent decades, some of which are positive, and others which are worrisome and may require policy changes. At the other end of the range of possibilities, the economy might experience a larger shock, with accelerating changes in the job market, and significantly more workers in need of assistance and retraining as their skills no longer match the demands of the job market: "Given available evidence, it is not possible to make specific predictions, so policymakers must be prepared for a range of potential outcomes.” 
Because the effects of AI-driven automation will be felt across the whole economy, and the areas of greatest impact may be difficult to predict, policy responses must be targeted to the whole economy. In addition, the economic effects of AI-driven automation may be difficult to separate from those of other factors such as other forms of technological change, globalisation, reduction in market competition and worker bargaining power, and the effects of past public policy choices. Even if it is not possible to determine how much of the current transformation of the economy is caused by each of these factors, the policy challenges raised by the disruptions remain, and require a broad policy response.

The report suggests three broad strategies for addressing the impacts of AI-driven automation across the whole U.S. economy: Invest in and develop AI for its many benefits, educate and train Americans for jobs of the future; and aid workers in the transition and empower workers to ensure broadly shared growth.

A Swedish think tank, Futurion, has made a study of new forms of labour contracts in Sweden. These now forms, called "egenanställningar", still represents a small fraction of total employment, but are growing fast, up to 50 per cent a year. The report discusses the risks of a further development of such employment contracts, and provides a knowledge base for policy conclusions $^{78}$.

\section{Question marks by CEO on globalisation}

Executives running the world's leading companies share public scepticism about the benefits of globalisation, and doubt whether breaking down barriers to trade has helped tackle climate change or inequality.

The annual health check of global boardrooms 2017, conducted by the consultancy firm PwC, found the mood more upbeat than a year ago, despite the shockwaves caused in 2016 by the vote for Brexit and the victory of Donald Trump in the US presidential election. But the survey, published to coincide with the World Economic Forum in Davos in January 2017, found that the bullishness about the benefits of globalisation had diminished in the 19 years since PwC first polled executives at the end of the 1990s. The findings show that while business leaders are more positive in their outlook, their levels of concern about economic uncertainty (82\%), over-regulation (80\%), availability of key skills (77\%) remain very high. Worries about protectionism are growing, with 59\% of CEO concerned about protectionism, increasing to 64\% for CEOs in the United States and Mexico.

While positive on the benefits of globalisation in building the free movement of capital, goods, and people, CEOs question whether globalisation has done anything to close the gap between rich and poor or mitigated the issue of climate change. This contrasts with the first PwC CEO survey in 1998 when CEOs were positive about the drivers of globalisation. 58\% of business leaders think it has become harder to balance globalisation with rising trends in protectionism. The concerns contrast with their views in the first PwC CEO survey which reported 'the typical global corporation has as much freedom of trade as it needs'.

For the past 20 years CEOs have been largely positive about the contribution of globalisation to the free movement of capital, goods, and people. However, this year's survey respondents 
are sceptical that it has mitigated climate change, or helped close the gap between rich and poor. This is similar to the public's view on these issues, in a separate consumer poll commissioned by PwC of over 5000 people in 22 countries. Only 38\% of the public believed globalisation has had a largely positive impact on improving the movement of capital, people, goods and information, compared with $60 \%$ of CEOs. Almost two thirds (64\%) of the public believe globalisation has helped create full and meaningful employment, contrasting with over three quarters of CEOs (76\%). The public are also less convinced than business leaders that globalisation has created, to a large extent, a skilled and educated workforce (29\% of the public vs $37 \%$ of CEOs). Bob Moritz, Global Chairman, PwC, comments:

"Public discontent has the potential to erode trust which is needed for long term sustainable performance. The real challenge here though, isn't just one of how CEOs navigate, it's about the need for CEOs to have a deeper, twoway relationship with stakeholders, customers, employees, and the public. Understanding the root cause of the potential discontent or perception is a critical first step towards communicating the benefits of business for society. There's a lot at stake if we do not achieve inclusive global growth.”

\section{Global business: A new approach}

How will global corporation revise their strategies in the light of neo-nationalism and new trade restrictions? Boston Consulting Group has published an article on what this new phase can lead to. ${ }^{79}$ The theme is that "Globalisation is not dead, but it is different". The globalisation as we know it has been centred around the idea of integrating the rest of the world with Europe and the US through flow of money, goods, services and people; now digitisation and decentralisation will disrupt the old model: The singular system with a dominant economy (for a long time the US), with a dominating new technology, and common governance (Washington consensus), will be replaced by a multi-polar and diversified world.

What we will see is the growth of a new, more decentralised governance system, a more complex and volatile system, with local and regional regulations aiming at achieving a new balance between national interest and global logic. G7, G20, WTO will be unable to establish common regulations to the same extent as before. An example: In 1995, 50 regional trade agreements existed, now there are 280; the era of the big WTO-agreements are over.

The engagement of Governements in business has increased during the past 10 years; the total value of "sovereign wealth funds" has more than doubled since 2008 and the share of business in which the majority are state funds has increased from 9 percent in 2005 to 23 percent in 2014, according to Fortune 500: "Thus public capital has become as important as private capital."

This new global economy will be less dependent on trade and more dependent on domestic demand and efforts to increase productivity. According to Boston Consulting Group, all factors together, will push companies to reconsider their global business models and find more country specific models. Re-adjustments are already underway and is confirmed by statistics on trade, capital flows and direct investments. "It is time for a bold pivot...in the face of a protectionist global environment...We will localise. In the future, sustainable growth will require a local capability inside a global footprint”, according to Jeff Immelt, CEO of 
General Electrics. Another business manager described the new business strategies as followed: "Scale curves are flattening, and the cost advantage of low-cost labor evaporates if you calculate the total cost of ownership of shipping goods around the world from a low-cost factory."

\title{
A massively changing global economy?
}

In order to understand the last 30 years of globalisation, and the future in front of us, we must also understand demographic development, what it has meant and it will mean. These issues have been studied in an analysis, Long-Term Asset Return Study, by researchers at Deutsche Bank $^{80}$. A central conclusion is that the current era of globalisation has come to an end, and that the global economy will change massively during the upcoming 30 years. The analysis is built on the idea on global economic and political development as long waves:

\begin{abstract}
"In relatively modern economic history we saw the first wave of globalisation between around 1860-1914; we then saw the interwar period which included an ill fated return to the Gold Standard between 1925 and various points in the 1930s depending on when individual countries subsequently left. Then post-WWII, we saw the Bretton Woods system that lasted around a quarter of a century (1945-1971); and this was followed by the high inflation period of the 1970s. You can break up economic history into alternative distinct periods but these broad eras have shaped economies, politics, policies and asset performance."
\end{abstract}

What has occurred during the last 30 years can be explained by "a perfect storm of factors": The return of China in the global economy, the fall of the Soviet Union and partly to the economic liberalization of India. These factors have together led to an addition of one billion persons to the global labour market:

"This has coincided with a general surge in the global workforce population in absolute terms and also relative to the overall population, thus creating a perfect storm and an abundance of workers."

The demographic expansion has now culminated, and we will in the upcoming 30-40 years, witness the global economy "changing massively":

"With demographics deteriorating it seems highly unlikely that the next couple of decades (possibly longer) will see real growth rates returning close to their pre-crisis, pre-leverage era levels. Obviously if there is a sustainable exogenous boost to productivity, then a more optimistic scenario .... can be painted. At this stage it is hard to see where such a boost comes from - and even if it does, time is running out for it to prevent economic and political regime change given the existing stresses in the system..... The dominant themes, until the end of the next era in around 2060, will include lower GDP, higher real wages, higher nominal GDP (for most), greater controls on immigration, higher taxes for the wealthy, and lower levels of international trade.” 
However, this demographic perspetive is contested. China has a very low retirement age, and plans to raise it in stages from 2017, which will add millions to he world's labour force. Meanwile, in India, hundreds of millions of people will move from the rural economy into cities and to the global wage-labour market. "There is little prospect of a global labour shortage pushing up wages in rich countries for many years to come." ${ }^{81}$

\section{Globalisation and globalism - a Chinese perspective}

We are used to seeing globalisation from the West's perspective, as we have been living the long wave of globalisation. This long wave looks different from a Chinese perspective, as explained in an article in Foreign Affairs by Eric X. Li, a Shanghai venture capitalist, a member of the council of the International Institute for Strategic Studies. and a director of China Europe International Business School and a Henry Crown Fellow of the Aspen Institute. He describes, in an article in Foreign Affairs, globalisation as an innocent concept, which started in the $1970 \mathrm{~s}^{82}$ : "The world was becoming increasingly connected through trade, investment, travel, and information. But after the Cold War, it was injected with an ideological component; globalism. And now one can hardly distinguish between the two.”

Globalism is rooted in the neo-liberal doctrine of the Washington Consensus. It envisioned a world moving inextricably toward the adoption of a unified set of rules and standards in economics, politics, and international relations: "National borders would gradually lose relevance and even disappear. Cultural distinctions would give way to universal values. Electoral democracy and market capitalism would spread the world over. Eventually, all countries would be governed in more or less the same way."

The process would be backed by the United States' hard and soft power: "Indeed, it was partially according to this logic that neo-liberalism's offspring, the neo-conservatives and liberal interventionists, took America to war in Afghanistan and Iraq. And therein lies the problem; globalism was a Trojan Horse. It devoured globalisation, turning it into a force that seemed unstoppable until it collapsed under the weight of its own hubris.”

In the West, the leading disciples of globalism became its greatest beneficiaries. Wealth and power concentrated at the top, among the owners and deployers of capital, who favored free trade, multiculturalism, multilateral institutions, and even regime change and nation building in foreign lands. "But their vision harmed the vast majority that constituted the middle class. Just one generation after winning the Cold War, the United States saw its industrial base hollow out, its infrastructure fall into disrepair, its education system deteriorate, and its social contract rip apart.... In the name of globalisation .American elites had been building an empire at the expense of a nation.”

So, is this the end of globalisation? No, the death of globalism does not mean the end of globalisation as the idea was originally understood, according to Eric X. Li: "On the contrary, interconnectedness will probably continue to increase, driven by secular trends in technology and economics. Effective global governance, in other words, is needed more than ever. But it can no longer be based on the narrative of globalism.” 


\section{Globalisation - when the US closes its borders}

What will the new "America first" policies, launched by President Trump, mean for globalisation as we know it? Joscha Fischer, a former German Minister of Foreign Affairs, has made an analysis of the new situation in an op-ed in Social Europe ${ }^{83}$. He presents two important points. The first one is that the Trump administration:

“... does not intend to pursue business as usual. His motto, America first, signals the renunciation, and possible destruction, of the US-led world order that Democratic and Republican presidents, starting with Franklin D. Roosevelt, have built up and maintained, albeit with varying degrees of success, for more than seven decades. If America abandons its role as the leading economic and military power and moves toward nationalism and isolationism, it will precipitate an international reordering, while also changing the country itself. Rather than being a hegemon, the US will become one great power among many.”

The second point is a piece of advice to Europe to avoid anti-Americanism. In spite of all the dangers Trump’s presidency poses for Europeans, it offers opportunities as well:

“Trump's protectionist rhetoric alone has already led to a rapprochement between China and Europe. More important, the new US administration has furnished Europeans with a chance finally to close ranks, grow up, and reinforce their geopolitical power and position. But if Europeans finally do come together, they should avoid anti-Americanism. Trump is America's president, but he is not America. North Atlantic countries will still have a common history and shared values, even under Trump, and even though much else will change in the coming years."

\section{Globalisation: What is next?}

What conclusions can we draw from these different, partly confusing perspectives on globalisation? A first conclusion is that the financial crises was a watershed, marking a new strength and a new role of Non-Western countries, particularly China and India. These countries will remain committed to sustaining the international economic order of open markets and free flows of investment. After all, only through continued integration into the global supply chains of goods, services, people and knowledge can emerging markets meet the aspirations of their growing middle classes. ${ }^{84}$

What about the West? Here we see a lot of confusion. The leading role of the USA and Europe: what Eric X.Li called "globalism, seems to change. We have now three players with three different agendas. The USA with Donald Trump as president will be more inward looking. "Make Amerika Strong” or "America first” signals protectionism in different forms. The aim is to reduce the trade deficit to become less dependent on China to finance the balance of payment deficit. The EU, with the biggest single market in terms of purchasing power of 500 million consumers and millions of enterprises, is running a trade and current account surplus, partly due to several years of austerity, which has led to slow trade growth in Europe and globaly. 
The UK under Brexit seems to seek another direction. While the US is flirting with protectionism, the UK has delared it will become a global leader in free trade. It will do so by giving up membership of the EU Internal Market, and compensating this by seeking trade deals with the rest of the world. How this will work is far fram clear. The Japanese government has signaled that Japanse companies, making half of their European investment in the UK, are prepared to change investment strategies in favour of Member States in the EU27. Globalisation is not dead, it is different. And businesses are already adjusting the new world of uncertanity in trade and foreign direct investment.

\section{Any light at the end of the tunnel?}

For democracy and for progressive policies 2016 was a dark year. Are there any light in the tunnel to give optimism for 2017? Is there any room for reason, justice and solidarity in an increasingly polarised world?

\section{The Global Deal on Sustainable Development Goals}

The paradox here is that in this conflict-ridden and depressing world, all of the UN member states have agreed on the most ambitious global goals ever agreed on, for the global development and for the development of each country. All countries have made commitments to end extreme poverty, reduce inequalities and injustice in the world, to solve the climate crisis, and to do this through concrete measures within 17 different areas.

If the global development goals were to be incorporated into government policy in all member countries, we could look at the future with confidence. However, the shift of power and the deep political division in the US and in Europe with growing support for right wing parties, casts a dark shadow in our part of the world. Where in this political environment is there room for the global development goals?

\section{Rethinking EUs macroeconomic policies}

Let us review what is happening in the EU. The criticism on the construction and the implementation of the EU Stability and Growth Pact (SGP) comes from many sources. The criticism by OECD in Economic Outlook $2015^{85}$ is diplomatically formulated, though sharp in substance. OECD argues for a well-designed fiscal framework in a monetary union, not least in order to counteract "pro-cyclical” politics, i.e. a politics reinforcing the economic fluctuations.

According to the OECD, the way in which the current EU framework is applied today raises critical questions on the regulations on budget deficit, on the budget balance in a medium term as well as on the national debt in relation to GDP. With respect to these issues the current framework has rather contributed to reinforcing the problems. These are diplomatic formulations. In layman's terms, this is serious criticism on how the EU Stability and Growth Pact (SGP) has been functioning during a protracted financial crisis.

I believe that the strong focus on fiscal targets for each country in the EU Stability and Growth Pact (SGP) has made it difficult to take advantage of the growth potential of the 
internal market in Europe with 500 million consumers. When looking at Europe as " an entity”, it turns out that more than 80 percent of the goods and services we use in Europe in consumption and investment comes from within the internal market.

Having this as a starting point for the economic growth policy, the conditions are quite different than if you restrict the perspective to each individual country. If each country is to cut public spending to meet stability requirements, then not only is domestic activity limited but also the activity of EU as a whole. A single country could starve itself to increased competitiveness, but all EU countries cannot do it at the same time. A political framework for each country to bring about an export-led growth by reducing domestic demand rather leads to all countries importing unemployment. If all countries instead co-ordinate their policies to increase growth, each country can take advantage of both their own and their neighbours' actions. This argument has been put forward by amongst others Kemal Dervis, former vice president of the World Bank: ${ }^{86}$

\begin{abstract}
"In Europe, where countries are closely linked by trade, a co-ordinated strategy that allows more time for fiscal consolidation and formulates growth-friendly policies would yield substantial benefits compared to individual countries' strategies, owing to positive spillovers.”
\end{abstract}

Since a few years back, a reorientation is going on. In January 2015 ECB initiated an expansive monetary policy with 0-interest rates and QE (Quantitative Easing) in order to save the euro (Draghi: "Whatever it Takes to Save the Euro"). Parallel to this, the European Commission has signaled a new orientation of macroeconomic and social policies ${ }^{87}$. The reorientation has been going on, slowly and quietly, more loudly in rhetoric, "a triple A Social Europe", since 2014. With the macroeconomic guidelines for 2017 the signals are much clearer:

- Pursue policies that support growth in the short and the long term, and improve adjustment capacity, rebalancing and convergence.

- Strengthen the recovery through a fiscal expansion of up to 0.5\% of GDP in 2017

- Implement reforms that promote job creation, social fairness and convergence, underpinned by an effective social dialogue.

\title{
Rethinking economic and social policies
}

On a broad international front a 'rethink' is underway in terms of economic policy and redistribution policy. In addition to a new Washington Consensus, which IMF, World Bank Group, OECD and ILO presented before the 2016 G20-summit, many leading economists share this insight. One exemple is Nouriel Roubini, "Dr. Doom”, writing that:

“... the backlash against globalisation is real and mounting in advanced economies. But it can be managed through policies that ensure that the benefits of globalisation continue, that mitigates collateral damage to those who lose out and makes losers more likely to eventually join the ranks of the winners." 88 
A similar message comes from Larry Summers, former Minister of Finance in the US, writing that international agreements should not be judged by the extent to which they are harmonised or the number overcome obstacles, "but whether citizens are empowered." A similar conclusion is found in the previously referred McKinsey report that in the last sentence sums up the message like this: "The trend of flat and falling real incomes merits bold measures on the part of government and business alike." ${ }^{89}$

In the Financial Times Martin Wolf writes that economic policy must promote " the interest of the many, not the few": "The failure, a profound one, lies in not ensuring that gains were more equally shared, notably within high income economies. Equally dismal was the failure to cushion those adversely affected.” ${ }^{90}$ Managing director at IMF, Christina Lagarde, pointed out the message of IMF in an interview during the G20-summit in China September 2016 by connecting the political development with the development of income and the income distribution:
"Weak global growth that interacts with rising inequality is feeding a political climate in which reforms stall, and countries resort to inward- looking policies. In a broad cross-section of advanced economies, incomes for the top 10 percent increased by about 40 percent in the past 20 years, while growing only very modestly at the bottom. Inequality has also increased in many emerging economies, although the impact on the poor has sometimes been offset by strong general income growth. Forceful policy actions are needed to avoid what I fear could become a low-growth $\operatorname{trap}^{91}$."

The demand for a new growth model is now coming from more and more places, even from the ECB. President Mario Draghi, sent a strong message to the policy makers advocating an ambitious redistribution policy: ${ }^{92}$

"What is different from the past .... is that today we must devote more attention to the redistributive aspects of integration, and especially to those people who have paid the highest price. I do not think there will be significant progress in terms of opening up markets and competition if Europe does not listen to the demands of those left behind by a society built on the pursuit of wealth and power"

President Juncker has taken the initiative to review and strengthen the European social model by introducing a European Pillar of Social Rights ${ }^{93}$. In his first State of the Union President Juncker said: "I will want to develop a European Pillar of Social Rights, which takes account of the changing realities of the world of work, and which can serve as a compass for the renewed convergence within the euro area”. Since the announcement of the European Pillar of Social Rights in September 2015, there has been a wide debate with EU authorities, member states, social partners, civil society and citizens on the content and role of the Pillar, and how to ensure fairness and social justice in Europe. The Pillar has been conceived as a reference framework to screen the employment and social performance of participating Member States, to drive reforms at national level and, more specifically, to serve as a compass for the 
renewed process of convergence across Europe. Thus, the ambition is to make economic and social policies two sides of the same coin.

The questions is how fast this change can go and creating results that enables that confidence in the EU can be rebuilt. The current forecasts for recovery and growth provides no strong signals. What many people are experiencing in their everyday lives is still the impact of austerity measures, unemployment and deteriorating social conditions. A new start for Social Europe is depending on what Member States are prepared to do: what they can agree to on European level, and what they are doing at national level to turn austerity policies into new inclusive growth models.

\section{A concerned citizen's questions to the next generation of progressive policy makers}

When I started drafting this article, ” to understand the times we are living through?”, my intention was to trace the roots of the political discontent in the West. After Brexit in the UK and the political conventions in the US, I could imaging a nightmare scenario: A Europe in political disintegration under leadership of Britain's Conservative government in parallel development of nationalist parties in France, Germany, Poland, Hungary, with a calculating president Putin in the East and an eccentric and moody president Trump in the West, isolating the US behind new borders, and embracing President Putin. Today, we know that these are "the times we are living through".

It will still take a while before we know what Brexit means, and before we fully understand the consequences of the new Trump regime for the US and for the rest of the world. And how the US administration will work with its political supporter, Presiden Putin in Russia, and with financial support from president Xi in China, the "bank of last resort" for funding of the US trade deficit.

Have I become wiser? Somewhat, but the dilemma is that we only fully understand the times we live through once we can look back in retrospect. Nevertheless, I think we have to realise that the next four to eight years will be dominated by neo-nationalism and regressive policies. This is a period which has to be used to rethink the ideas and theories that imploded in the financial crises 2007-2008, and the trickle down theories that undermined the social contract by rewarding the few and leaving other behind.

The purpose of this article is not to present such new ideas and theories. The purpose is more limited: It is to better undertstand why our open liberal socities are challenged, and why progressive policies are replaced by regressive policies. In this last chapter I will sum up problems identified in this article, presenting them in the form of a concerned citizen's questions to the next generation of progressive economists, scholars and policy makers. It is for the new generation, not my generation, to come up with the new ideas, theories, intellectual tools and political strategies for a new reform agenda for the 2020s.

How to fight an economic crises: Without ammunition? 
The first and the most immediate question concerns the macroeconomic policies. Still, eight years after the financial crisis, a fundamental concept of what a well-functioning economic development could look like is missing, as Larry Summers has pointed out. Structural policy measures, in combination with the anti-inflationary monetary policy, as recommended by the IMF and others, have in recent years been replaced by unprecedented monetary activism with zero-interest rates and expansive lending to banks, first in the United States, then in Europe.

Though it has not led to anything that can be described as "normal", this is a weakness which is described by the conciliatory formulation "the new normal", something we are expected to get used to. The Fed has now started to increase interest rates and will do more in 2017, the ECB will have to continue supporting recovery in Europe.

\section{Long-term interest rates}

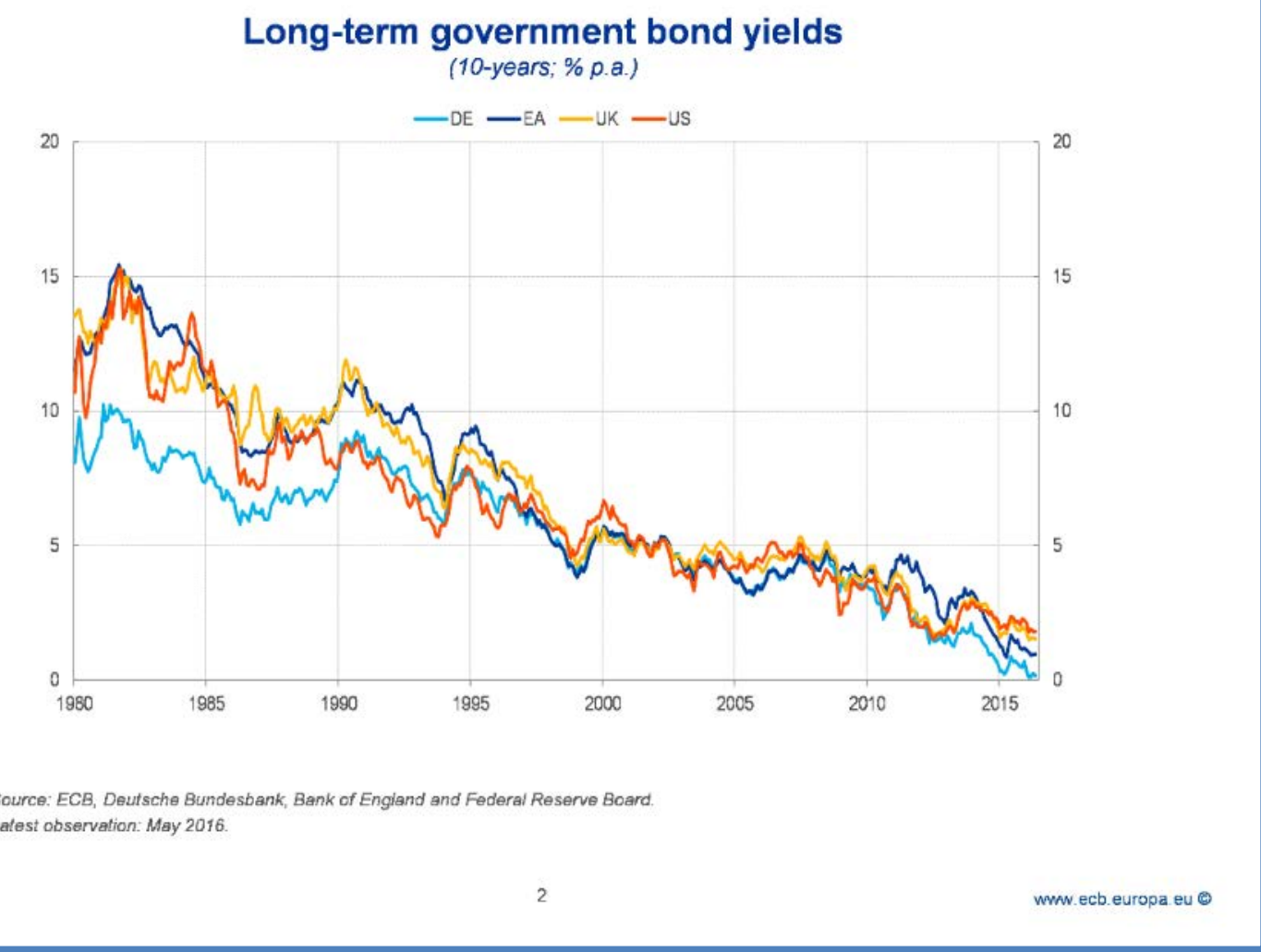

Figure 16: Long-term government bond yields

The weakness of the current state is, according to Larry Summers, that central banks will not have the necessary space, to handle an incipient slowdown of the economy:

"To an extent that is underestimated in some quarters and understated in others, the world economy is far more brittle than usual, because of the inability almost everywhere to lower interest rates substantially. Normally, in response to incipient downturns central banks lower rates by 400 basis points or more. Nowhere do they have that kind of room. Nor is there large scope for reducing term and credit spreads given their very low levels. This 
is no time for austerity. Greater use of fiscal policy should be on the agenda almost everywhere and certainly with the change of government in the UK." 94

To sum up: Monetary policies are exhausted and have no room for action, when we face the next downturn. Fiscal policies in Europe are still based on the idea that austerity regimes can deliver fiscal consolidation, while facts tell us that such consolidation only can be attained through economic growth. Finally, structural policies of the past has not delivered, and "more of the same" will not deliver higher productivity unless there is economic growth. We badly need a new convincing macroeconomic strategy, replacing the old orthodoxy that has been practiced in Europe.

How to manage the "much broader and deeper" financial system problems?

There seems to be a broad consensus that the ongoing reforms of the financial markets will not solve our probles. "The world is doomed to an endless cycle of bubbles, financial crisis and currency collapses”. That was one conclusion from the discussion at the Jackson Hole meeting 2013. "All their discussions of the international financial system were marked by a fatalist acceptance of the status quo ... we still have no way to tackle imbalances in the global economy and that means new crisis in the future". Policy makers get caught up in the details of regulating "too Big to Fail” banks, but the problems in our market system are much broader and deeper than that, writes Rana Foroohar in "Makers and Takers” (2016).

Who will take the initiative to rethink the financial system, making it a servant of the real economy, not a status quo system, mainly serving the interests of the financial system itself? This is an extremely difficult task, all the more challenging, now when the Trump regime is backtracking, weakening the legal framwork of the finacial system.

\section{How to reconcile slow growth and widely shared prosperity?}

The third question: How to reconcile slow growth and widely shared prosperity, is as big a challenge as the first two questions on a new macroeconomic strategy, and a new order of the financial system. Remember that message from “The Rise and Fall of American Growth", that there is not any hope for a revival of productivity in the years to come. On the contrary, there are several headwinds, which will leave virtually no room for growth over the next 25 years in median disposal real income per person. One such headwind is rising inequality ${ }^{95}$. Remember also the message that growing inequality is not only a social problem, but also an economic problem, an obstacle to economic progress. It is in itself an enormous challenge to bring about a shift from increasing income inequality to widely shared prospserity, i.e. to reverse an income distribution trend that has continued for over 30 years, and which is supported by strong vasted interests.

To bring about such a shift, in an economic climate of stagnating productivity and slow economic growth, seems overwhelming. Nevertheless, this is a task that political parties and elected politicians in governments and Parliaments will have to address in the years to come. Growth and distribution will have to be treated as two sides of the same coin. 
How to make globalisation work for the many, not only the few?

My fourth question is close to question number three on growth and shared prosperity. The difference is that focus is on the role of trade. Globalisation in the form of trade and foreign investment has freed productive forces and promoted innovations, and contributed to millions of people moving out of poverty, particularly in China, India and other Asian countries. However, it became a dividing force in the West, as illustrated by the famous "elephant curve" on global income distribution over 30 years, from 1988 to $2008^{96}$. Enormous amounts of wealth and power have been concentrated among small minorities while leaving many behind, causing growing inequality and instability in the global financial system.

There is a growing consensus on the need to find new ways and means to reverse this process, not least in the light of the attacks on globalisation. One new voice is the head of the Europan Central Bank, Mario Draghi; central bankers seldom contribute to the debates about social policies. However, Mr Draghi has done that, and he has presented a very powerful message: "I do not think there will be significant progress in terms of opening up markets and competition if Europe does not listen to the demands of those left behind by a society built on the pursuit of wealth and power."97

There are many obstacles to such a new approach. One is the theories of international trade. They have evolved over a long period of time and helped us better understand the role of trade and the driving forces behind trade. The theories have also been used to promote, regulate and manage trade ${ }^{98}$. The focus has been on the mutual benefits of trade for participating nations, not on the wider effects of trade on income distribution in a country, and the need for policies in support of widely shared prosperity. The policy conclusions have rather been to regard social policies as impediments to free trade, rather than flanking policies, which are necessary for a fair distribution.

Here is a wide field for new ideas on the integration of trade, income and social theories, to further develop an intellectual basis for public policies for building a stronger foundation for new models for inclusive economic growth.

Are we entering the Dark Valley - towards the end of democracy?

In the introduction to this article I posed the question: Are we anew entering The Dark Valley, as the British historian Piers Brendon described the 1930's. I read the 700-pages book a few years after it was published in $2000^{99}$. At that time the dark history of the 1930 s was far away. We were living in a period of peace, prosperity and positive expectations. It was a period when the neocon Francis Fukuyama caught the interest of a broad audience by his book with the title "End of history and the Last Man”, published 2002. ${ }^{100}$

He believed that western liberal democracy, with its elegant balance of liberty and equality, could not be bettered; that its attainment would lead to a general calming in world affairs; and that in the long run it would be the only credible game in town. "What we are witnessing," he wrote, "is not just the end of the cold war, or a passing of a particular period of postwar history, but the end of history as such, that is, the end point of mankind's ideological evolution 
and the universalisation of western liberal democracy as the final form of human government."

Today, Brendon's book might be more relevant than Fukuyama's. Brendon was concerned to convey the lessons of the 1930's, above all how to ensure that economic crisis never again jeopardises political stability. However, even if there are great differences between our time and the 1930s in terms of technology, prosperity and international order, there are many similarities in political developments. We are witnessing a mix of reactionary conservatism and neo-nationalism in the USA and in Europa of many different form: From The Tea Party and Trump in the USA to illiberal regimes in Poland and Hungary to imperial Brexit ambitions in the UK and the neo-nationalistic forces in the Netherlands, France, Italy, Austria, Scandiavia and Germany, challenging the governing parties, eager to break up the European Union.

In the USA we have seen how an election campaign can be organised to use lies and smear to undermine opponents, and how foreign regimes can interfere in national elections. "The essence of the past-fact threat to democracy is that entirely false claims.... wrapped up in emotionally appealing narratives and constantly magnified in online echo chambers, seem to have aquired the power to sway a significant part of the electorate ${ }^{101}$. There is a great risk that this form of manipulation will become "the new normal" in the upcoming elections in 2017 in the Netherlands, Italy, France and Germany.

Will illiberal leaders in Europe and in the USA, when elected, respect democratic institutions and traditions? We have seen what the regimes in Hungary and Poland can do to undermine democratic institutions and values. Will the new Trump administration, with a selection of billionaires and generals in the most powerful positions, do the same with the US political system? Will they, when the next election comes, allow a democratic process on equal terms, or will they use political and digital power to introduce authoritarian systems?

Do not despair, Timothy Garton Ash, Oxford, urges: "If Orwell and Solzhenitsyn did not surrender in the face of Goebbels and Stalin, it would be pathetic for us to give up now. There are numerous ways in which the post-fact threat can be countered to make 2017 the year antipost-fact." 102 Will Liberals, Christian Democrats and Social Democrats in Europe renew themselves and come out of the shadow of "unfettered globalisation" and austerity and form a credible political force for the fight against the illiberal authoritarians, those who are marching in the streets in Europe, and those now taking control of the Office of the President of the United States and entering into Parliaments in Europe, with active intervention by Russia ${ }^{103}$ ? The task is daunting, time is short.

\section{About the author:}

Senior advisor, Global Challenge, a Stockholm based think tank.

A former Finance Minister, a former Director General of the EU Commission and a former Chairman of the Board of Lund University. 
${ }^{1}$ Peter Baker et al, New York Times, November 9 2016,

2 Peter Baker et al, New York Times, November 9 2016,

${ }^{3}$ Anne Appelbaum, Washington Post, December 22, 2016

https://www.washingtonpost.com/news/global-opinions/wp/2016/12/22/illiberaldemocracy-comes-to-poland/?utm term $=.778396$ ceb5ee

${ }^{4}$ http://www.imf.org/external/pubs/ft/fandd/2003/09/pdf/clift.pdf ; https://sv.wikipedia.org/wiki/Washington_Consensus\#Referenser

${ }^{5}$ Andre Sapir, http://bruegel.org/2014/07/the-great-transformation-memo-to-the-incomingeu-presidents/

${ }^{6}$ This section summarizes what I wrote on "The long wave" in my Memo books "Bryta ny mark" and " Min europeiska resa", Gotlandsbokan in 2014 \& 2015, respectively.

${ }^{7}$ Turner: Between the Debt and the Devil, 2015

${ }^{8}$ Raghuram G. Rajan: The Fault Lines, 2010. Professor at Chicago Booth School of Business, then chief economist at the World Bank, later Governer of the Indian Central Bank.

${ }^{9}$ Turner: Economics after the Crisis, 2012

${ }^{10}$ Greenspan: The map of the territory, 2013.

${ }^{11}$ http://www.telegraph.co.uk/news/uknews/theroyalfamily/3386353/The-Queen-asks-why-no-one-saw-thecredit-crunch-coming.html

${ }^{12}$ Alan Blinder, After the music stopped, 2013.

${ }^{13}$ Growningen Growth and Development Centre and Conference Board: Council of Economic Advisors, published by the Economist.

${ }^{14}$ https://www.ceps.eu/system/files/DG\%20StructuralReforms.pdf

${ }^{15}$ The Economist, 8 October 2016.

${ }^{16}$ Robert J Gordon: The Rise and Fall of American Growth, Princeton Press, 2016

${ }^{17}$ Prospects for economic growth in the 21st century, - A survey covering mainstream, heterodox and scientifically oriented perspectives by Eva C. Alfredsson J. Mikael Malmaeus

${ }^{18}$ Joseph Stiglitz http://evonomics.com/joseph-stiglitz-inequality-unearned-income/

${ }^{19}$ The Economist: Shooting an elephant, September 16, 2016, http://www.economist.com/news/finance-and-economics/21707219-chartingglobalisations-discontents-shooting-elephant

${ }^{20}$ McKinsey: "Poorer than their Parents", 2016. http://www.mckinsey.com/globalthemes/employment-and-growth/poorer-than-their-parents-a-new-perspective-on-incomeinequality

${ }^{21}$ Thomas Piketty, Capital in the Twenty-First Century, 2014.

${ }^{22}$ http://www.oecd-ilibrary.org/deliver/fulltext?itemld=/content/book/9789264258303en\&mimeType=freepreview\&redirecturl=http://www.keepeek.com/Digital-AssetManagement/oecd/economics/the-productivity-inclusiveness-nexus 9789264258303en\&isPreview=true

${ }^{23}$ OECD, Back to work, http://www.oecd-ilibrary.org/employment/back-to-workfinland 9789264264717-en

${ }^{24}$ Nicolas Eberstadt: Men without Work: Americas Invisible Crisis, Templeton Press, 2016

${ }^{25}$ Lawrence Summers "Out of the game" in Financial Times, September 24, 2016. 
${ }^{26}$ http://eur-lex.europa.eu/legal-content/EN/TXT/PDF/?uri=CELEX:52016SC0051\&from=EN page 34

${ }^{27}$ Paul Romer, Stern School of Business, New York University, Delivered January 5, 2016 as the Commons Memorial Lecture of the Omicron Delta Epsilon Society.

${ }^{28} \mathrm{http}: / /$ www.aftonbladet.se/ledare/ledarkronika/katrinemarcal/article23294121.ab

${ }^{29}$ The Economist, 8 October 2016 http://www.economist.com/news/briefing/21708216americas-president-writes-us-about-four-crucial-areas-unfinished-businesseconomic?fsrc=scn/tw/te/pe/ed/thewayahead\&utm content=buffer3d286\&utm medium=s ocial\&utm source=twitter.com\&utm campaign=buffer

${ }^{30}$ Martin Wolf, FT, How Barack Obama rescued the US economy, January 21, 217

${ }^{31}$ Sara O'Connor, FT, Jobs for the boys is just half the story in America, February 8, 2017.

${ }^{32}$ Michael Tesler, UCLA https://www.washingtonpost.com/news/monkey-

cage/wp/2016/08/01/trump-is-the-first-republican-in-modern-times-to-win-the-partysnomination-on-anti-minority-sentiments/

${ }^{33}$ Financial Times, Edward Luce: One Nation Divided, 16 July, 2016

${ }^{34}$ Simon Schama," Clinton has a chance to repair the fabric of an angry America", FT October 29.

${ }^{35}$ Bo Rothstein, Social Europe, 19 January 2017

${ }^{36}$ http://edition.cnn.com/election/results/president

37 John Henley, The Guardian, November 9, 2016.

${ }^{38}$ Anatole Kaletsky, Social Europe: Trumping Capitalism, January 23, 2017, https://www.socialeurope.eu/2017/01/trumpoing-capitalism/

${ }^{39}$ Simon Kuper, Financial Times, July 7, 2016

${ }^{40}$ Zolt Darvas, Bruegel http://bruegel.org/2016/07/brexit-vote-boosts-case-for-inclusivegrowth/

${ }^{41}$ David Aaronovitch, The Times, Ugly truth about rise of Trump and Brexit, October 19

${ }^{42}$ Anatole Kaletsky, End Of The Backlash Against Modernity If Trump Loses, Social Europe, November 4, 2016

${ }^{43} \mathrm{http}: / /$ www.manchester.ac.uk/discover/news/new-eu-referendum-british-election-studydata

${ }^{44}$ Philip Stephens, FT, October 21; A hard Brexit heralds a closed Britain

${ }^{45}$ The Guardian, 1 October 2016, https://www.theguardian.com/money/2016/oct/01/theresa-may-hires-former-tony-blairpolicy-boss-to-review-workers-rights?CMP=twt_gu

${ }^{46}$ The Times, May ditches Thatcher and Cameron, January 8, 2016.

${ }^{47}$ Martin Wolf, Financial Times, May's policies make a mockery of her rhetoric, February 10 , 2017

${ }^{48}$ Resolution Foundation, Daniel Tomlinson, No country for young men? February 9, 2017

${ }^{49}$ Philip Stephens, FT, October 21; A hard Brexit heralds a closed Britain.

${ }^{50}$ Desmond Cohen, former Dean, School of Social Sciences at Sussex University, https://www.socialeurope.eu/2016/10/exchange-rate-folly-british-government-lostplot/https://www.socialeurope.eu/2016/10/exchange-rate-folly-british-government-lostplot/ 
${ }^{51}$ http://www.ons.gov.uk/economy/economicoutputandproductivity/productivitymeasures/ bulletins/internationalcomparisonsofproductivityfinalestimates/2014

${ }^{52}$ The Guardian, Jonathan Freedland, https://www.theguardian.com/commentisfree/2017/jan/27/never-mind-the-optics-theresamays-us-dash-was-mortifying

${ }^{53}$ Eurostat and ECB calculations 54

http://ec.europa.eu/eurostat/tgm/table.do?tab=table\&init=1\&language=en\&pcode=teina22 $\underline{5 \& \text { plugin }=1}$

${ }^{55} \mathrm{http}: / /$ ec.europa.eu/eurostat/statisticsexplained/index.php?title=Balance_of_payment_statistics/sv\&oldid $=264945$

${ }^{56}$ Lord Turner: Between the Debt and the Devil, 2015

${ }^{57}$ Martin Sandbu: Europe's Orphan: The Future of the Euro and the Politics of Debt, 2015, ${ }^{58}$ EU: The Five Presidents Report, 2015,

${ }^{59} \mathrm{ECB}$, Philip Vermeulen, The recovery of investment in the euro area in the aftermath of the great recession: how does it compare historically? October 2016

${ }^{60}$ Aftonbladet, September 20, 2016,

${ }^{61}$ Svensk konkurrenskraft rankas i världstopp, SvD

${ }^{62}$ https://www.weforum.org/agenda/2016/08/these-are-the-world-s-most-innovativeeconomies?utm content=bufferd1876\&utm medium=social\&utm source=twitter.com\&utm campaign=buffer

${ }^{63}$ http://www.dn.se/debatt/sverige-bast-i-varlden-pa-hallbar-utveckling/

${ }^{64}$ http://www.usnews.com/news/best-countries/best-raising-children

${ }^{65}$ http://uk.businessinsider.com/sweden-does-the-most-good-for-humanity-2016$6 ? \mathrm{r}=\mathrm{US} \& \mid \mathrm{R}=\mathrm{T}$

${ }^{66}$ http://www.thelocal.se/20160602/sweden-now-the-goodest-country-on-earth

${ }^{67}$ OECD Economic Surveys: Sweden 2017

${ }^{68}$ http://www.europaportalen.se/2016/08/sverige-fortsatt-invandringspositivast-i-eu

${ }^{69}$ Elvire Fabry in Euractiv : Fear of TTIP, globalisation, or a middle class downgrade?

${ }^{70}$ The Economist: http://www.economist.com/news/briefing/21702748-new-divide-richcountries-not-between-left-and-right-between-open-and

71 Tim Vlandas and Daphne Halikiopoulou, "Why far right parties do well at times of crisis: the role of labour market institutions University of Reading.

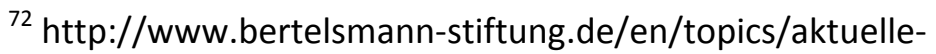
meldungen/2016/november/globalisation-fears-weigh-heavily-on-european-voters/

${ }^{73}$ Martin Wolf in FT, The Tide of Globalisation is turning, 8 September 2016.

${ }^{74}$ https://www.socialeurope.eu/2016/08/halt-global-trade-growth-rise-neo-mercantilism/

${ }^{75}$ Arancha Gonzales, Execitive-Director, International Trade Centre, The future of trade could be good, bad - or just plain ugly, World Economic Forum, February 9, 2017

${ }^{76}$ Bundesministerium fur Arbeit: http://www.bmas.de/EN/Services/Publications/arbeiten-40-greenpaper-work-4-0.html

${ }^{77}$ https://www.whitehouse.gov/blog/2016/12/20/artificial-intelligence-automation-andeconomy 
${ }^{78}$ http://futurion.se/utmanar-villkoren-pa-arbetsmarknaden/

${ }^{79}$ BCG: https://www.bcgperspectives.com/content/articles/globalization-growth-what-needknow-globalization-radical-new-phase/

${ }^{80}$ Deutsche Bank, Long-Term Asset Return Study, by Jim Reid, Nick Burns, and Sukanto Chanda

${ }^{81}$ Guy Standing: The Corruption of Capitalism, Biteback Publishing, 2016.

${ }^{82}$ Eric X. Li: Foreing Affairs, December 9, 2016.

${ }^{83}$ Joscha Fischer, Germany, Trump And The World, Social Europe, January 31, 2017

${ }^{84}$ Robin Niblett: Liberalism in Retreat, Chatham House, December 2016

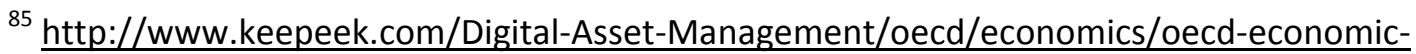
outlook-volume-2015-issue-1 eco outlook-v2015-1-en\#.V8IRMJAVjVI\#page50 - page 48

${ }^{86}$ Kermal Dervis: Austere Growth, 2012.

${ }^{87}$ http://ec.europa.eu/europe2020/pdf/europe2020 guidelines part1 en.pdf

${ }^{88} \mathrm{http}$ ://www.huffingtonpost.com/nouriel-roubini/globalization-politics b 11655494.html

${ }^{89}$ McKinsey: "Poorer than their Parents", 2016.

${ }^{90} \mathrm{FT}$, September 8, 2016. The Tide of Globalisation is turning.

${ }^{91}$ https://blog-imfdirect.imf.org/2016/09/01/we-need-forceful-policies-to-avoid-the-lowgrowth-trap/?hootPostID=d20429fb3088caab409553b782bc756f

${ }^{92}$ ECB, Mario Draghi, Trento, 13 September 2016

${ }^{93} \mathrm{http}$ ://ec.europa.eu/priorities/deeper-and-fairer-economic-and-monetary-union/towardseuropean-pillar-social-rights_en

${ }^{94}$ Summers: http://blogs.ft.com/larry-summers/2016/06/24/the-waves-from-brexit-start-tospread/

${ }^{95}$ Robert J Gordon: The Rise and Fall of American Growth, Princeton Press, 2016

${ }^{96}$ The Economist: Shooting an elephant, September 16, 2016, http://www.economist.com/news/finance-and-economics/21707219-chartingglobalisations-discontents-shooting-elephant ${ }^{97}$ https://www.ecb.europa.eu/press/key/date/2016/html/sp160913.en.html

${ }^{98}$ http://2012books.lardbucket.org/books/challenges-and-opportunities-in-internationalbusiness/s06-01-what-is-international-trade-th.html

${ }^{99}$ Piers Brendon: The Dark Valley, 2000.

${ }^{100}$ Francis Fukuyama: End of history and the Last Man, 2002

${ }^{101}$ Timothy Garton Ash: What to do when the truth is found to be lies, FT, December 24, 2016.

${ }^{102}$ Timothy Garton Ash: What to do when the truth is found to be lies, FT, December 24, 2016.

${ }^{103}$ https://www.dni.gov/files/documents/ICA_2017_01.pdf 